\title{
Mahāyāna Sūtras in Khotan
}

\section{Quotations in Chapter 6 of the Book of Zambasta $(I)^{*}$}

\author{
Ruixuan Chen
}

Heidelberg University

ruixuan.chen@asia-europe.uni-heidelberg.de

\section{Diego Loukota Sanclemente}

University of California, Los Angeles

diegoloukota@g.ucla.edu

\begin{abstract}
In this article we propose a series of twenty-three new identifications of sources for chapter 6 of the Book of Zambasta, whose tradent claims to have quoted a verse "from each sūtra." In this installment we offer a detailed analysis of the first five newly identified quotations, highlighting their place within Mahāyāna and Khotanese literature.
\end{abstract}

\section{Keywords}

Khotan - Book of Zambasta - Mahāyāna Buddhism - Gaṇdavyūha - Lalitavistara Vimalakìrtinirdeśa - Avaivartikacakra - Tathāgataguhya $(k a)$

* The research leading to the present article is the outcome of an online Khotanese reading group, which was held on a weekly basis from September 2015 to August 2016. The members of the reading group were the authors of the present article, Meghan Howard (Berkeley) and Warner A. Belanger, III. We would like to express our gratitude to the other two participants who also made considerable contributions to the findings presented in this article, which should be duly acknowledged as a collective achievement. Warner, moreover, helped polishing our English. For insightful comments on earlier drafts which make the paper by far the better, we are grateful to Prof. Jonathan A. Silk (Leiden), Prof. Jens-Uwe Hartmann (Munich), and the two anonymous reviewers. It goes without saying that any errors that remain are our own. 
In memoriam Ludovici Oscaris Gómez Rodríguez (1943-2017)

avidi in buddhica omnia, et eorundem peritissimi

\section{Introduction}

The tradent ${ }^{1}$ of the Book of Zambasta (henceforth Zambasta), whom we must honor as the most substantial literary figure in the extant corpus of Khotanese literature in spite of his ${ }^{2}$ anonymity, begins his chapter 6 in a manner that has constantly tantalized the students of ancient Khotan:

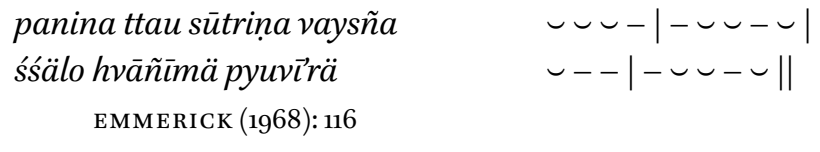

Of each sūtra thus for you now a verse (śloka) shall I preach: Listen!

The verses that follow this unique statement unfold in a cento of sorts that does not seem to concatenate the presumed quotations into syntactic or thematic

1 The poet, in a number of statements in the first person singular, describes his own activity as 'translating' (byūh-; 1.189, 23.2, 23.372), or 'preaching' (hvā̃n-; 2.244, 6.1, 9.1), or 'extracting' (thamj-; 14.98). From an emic perspective, modern western terms such as 'author', 'translator', and 'editor' seem to be out of place in the Khotanese context. As a replacement for those terms that are problematic in one way or another, we opt for 'tradent', a term which has been used by scholars of Rabbinic literature to indicate a producer of sacred text, who claims not to invent new doctrines, but merely to pass on ancient ones; see Jaffee (2007). This makes good sense in the present case, insofar as the Khotanese poet, more than once, expressed his concern for potential distortion of the meaning of the Buddha (cf. 1.19o, 8.48f.). For a pioneering and successful attempt at adopting this term into the field of Buddhist Studies, see Mayer (2015): 227-242.

2 Although literary activity was predominantly a male business in almost every pre-modern culture, one cannot exclude the possibility of a female hand in every single case. However, such an exclusion is possible in the case of Zambasta, because only the masculine perfect transitive forms are used in the tradent's statements in the first person singular (cf. 1.189 byüttaimä, 2.244 hvataimä, 14.98 thīyaimä etc.). 
patterns: Zambasta 6 appears as a collection of favorite sundry excerpts, somehow as Indian collections of subhāsitas rather than as an articulated whole. The very thematic pattern is mostly inconspicuous.

The advantages of knowing which texts the tradent quotes are obvious: such knowledge would provide us, at the very minimum, with a list of texts to which the tradent would have had access in his time, ${ }^{3}$ and which he considered important enough to include in this selection. We would also have, furthermore, a flurry of parallels in other languages that might elucidate the meaning and subtle nuances of some unclear or contested Khotanese terms. The chapter has exactly sixty verses, and if we consider the first to be introductory, then the number of quoted texts would be fifty-nine. Of these, three were identified by Ernst Leumann (6.3 = Saddharmapundạīka; $6.15=$ Vajracchedikā; $6.24=$ Suvarnabhāsottama $)^{4}$ and one by Duan Qing 段晴 $(6.41=$ Hastikakșya $) .{ }^{5}$ In the serial article that begins with this installment, we will present another twentythree proposed source identifications.

Before presenting our results, we would like to stress the significance of these finds. On the one hand, as we mentioned above, having parallels in other languages allows us to formulate improvements on previous interpretations of Zambasta. This is the case of Duan Qing's article on chapter 3 of Zambasta, ${ }^{6}$ in which the discovery of a Chinese parallel to the Khotanese text makes it possible to formulate a series of modifications to Emmerick's translation. The Khotanese language is still not fully understood: however one may assess the formidable developments of research into the language, it is still much less well understood than, say, Latin, Classical Chinese, or Sanskrit. Careful philological and linguistic work still has a long way to go in the realm of Khotanese studies, and it remains a priority for a language that celebrated not long ago a meager century of discovery. ${ }^{7}$

3 For the date of composition of Zambasta, see Maggi (2004). Maggi argues persuasively that the terminus ante quem is the late $5^{\text {th }}$ century $\mathrm{AD}$, revising earlier speculation on a later date, i.e. 7 th or 8th century; see Emmerick (1989): 363 .

4 These identifications are noted in Leumann 1933-1936: 92, 94, 96.

5 Duan apud Chen \& Liu (2014):294, n. 3. Prof. Duan has also communicated to the authors that she has identified a number of possible sources for Zambasta 6 (personal communication, June 30, 2017) and that she intends to publish her results soon. Some of her identifications apparently overlap with those presented here, and those must be acknowledged as independent discoveries.

6 See Duan (2007): 39-58.

7 Hoernle (1897) published Khotanese texts for the first time, although he was unaware of the nature of the language back then and thought it was proto-Tibetan. 
This being said, more knowledge about the sources of the tradent of Zambasta can throw light not only on the Khotanese language, but also on the ancient culture of Khotan itself, on its literary and religious traditions; in particular, on its own peculiar brand of Buddhism. The most prominent Khotanese scholars of the twentieth century were in general Iranists by training, and the exotic features of predominantly Buddhist pre-Islamic Khotan, halfway between India and China, have not always quenched their appetites. ${ }^{8}$

The modern biological descendants of the ancient Khotanese being largely unaware of and thus unconcerned with their pre-Islamic past, ${ }^{9}$ an interest in the ancient culture of Khotan in its own terms was not an immediate concern of researchers upon the discovery of the textual and archeological traces of the land, and has taken off slowly but surely only in the last decades. In the specific case of Khotanese Buddhism, Bhikkhuṇi Dhammadinnā (aka Giuliana Martini) has pioneered in the effort to consider the corpus of Khotanese Buddhist literature in its own logic. It is in a similar direction that we would like to address the work we present here.

The significance and implications of the corpus of proposed sources for Zambasta that we present here will be, we hope, a subject for debate. Not wanting to put forward premature points of view, we might instead here highlight for the reader what those likely points of debate might be.

Mauro Maggi's hypothesis ${ }^{10}$ that the texts quoted in Zambasta 6 represent a Khotanese sūtra-canon might hold true, but with some necessary caveats.

Most representative of this puzzlement is perhaps the most influential scholar of Khotanese studies in the twentieth century, Harold W. Bailey. Writing in 1985, after half a century of tireless work on Khotanese documents, Bailey declares: "[M]y own interest had at the first in 1934 been purely Iranist. I wished to draw out 'Middle Iranian' from those unexplored Mss with a view to advancing Zoroastrian studies. I have educed all the Iranian I can from the texts I have had in hand [...] I am now anxious to go back to more congenial Iranist work free from the mass of information required from Chinese, Tibetan and Turkish sources. The Avesta is, after all, the most exciting of Iranian materials. I can leave the Khotan-Saka field with the knowledge that there are solid workers to carry the study to its definitive solutions." (Bailey [1985]: vii)

9 Let one example suffice to illustrate this point. The word for 'Buddha' in modern Uighur is بو but, which is, however, a loanword from Persian. As in Persian, the modern Uighur word means 'idol' and carries with it all that word's negative connotations. Its counterpart in Old Turkic is burzan, lit. 'the Buddha-Khan', a compound whose first component goes back to 佛 fó, which was pronounced approximately bur in Northwest China in the $7^{\text {th }}$ and 8th centuries. In the Islamic period, like but, it came to mean 'idol' and survives in some Northeast Turkish languages, e.g. Tuvan burğan 'god, idol'. See Clauson 1972: 36of. 
In the first place, there is no evidence that, as among the Chinese, Tibetans, and Tanguts, in Khotan there may have been large translation bureaus with imperial sponsorship: the great variance in the translation techniques employed and the lack of terminological standardization, even within groups of texts, ${ }^{11}$ argue against coordinated efforts on a large scale. Therefore, it seems unlikely that the texts represented in Zambasta 6 were a well-defined collection. What we would have here at most is a list of texts to which the tradent might have had access in 5th-century Khotan, and that he considered authoritative.

This being said, the reader is bound to notice the close affinity that exists between our proposed identifications and the explicit outline of Mahāyāna bibliography that the tradent articulates in chapter 13 of Zambasta. Thus, the Buddhavalamtsaa (= Buddhāvatamsaka) category in 13.13 might encompass the Gandaryūha quotation in 6.5; the Mahāsandävāta (= Mahāsamnipāta) in the same verse (13.13) the Ratnaketuparivarta quotation in 6.20; etc.

Another caveat regards one of the most interesting and puzzling features of Khotanese Buddhist literature, namely the fact that some texts apparently circulated only in Sanskrit, others only in Khotanese. ${ }^{12}$ There are cases in which both Sanskrit and Khotanese versions seem to have circulated concurrently, but as to the relationship between those concurrent Sanskrit and Khotanese versions of the text, the evidence is contradictory. In the case of the Käsyapaparivarta, better known in Khotan as the Ratnakūla (Skt. Ratnakūta), ${ }^{13}$ although the Sanskrit and Khotanese overlap only marginally, there seems to be a general agreement with the Sanskrit recensions; ${ }^{14}$ although the Sanskrit text of the Sanghătasūtra is not attested in Khotan, the Khotanese version matches very closely the Sanskrit recensions from neighboring Gilgit. ${ }^{15}$ However, in the case of the Bhaișajyaguruvaiduryaprabhasūtra, the Khotanese and Sanskrit texts

of Zambasta [...] If all the subsequent lines could be identified, we would have, at least of the sūtras, a canon of fifty-nine texts as recognised in Khotan at the time of the Book of Zambasta."

11 See Maggi (2009): 343-346 and Skjærvø (2012): 126-134.

12 See von Hinüber (2014): $147 \mathrm{f}$. for a clear formulation of this model.

13 On the hybrid spelling of this title, see Martini (2011): 164.

14 See Martini (2011): 172-173. In a newly identified folio, the Khot. rendering aysu jsāna cu kūsämä 'What am I seeking?' mirrors exactly the reading attested in the main Sanskrit manuscript (also from Khotan) kim aham margāmìti 'What am I seeking?', which is an error for kim aham arghāmīti 'What am I worth?'; see Maggi (2015): 111, 119. This shared error hints at the affinity between the two versions of the Kásyapaparivarta.

15 See Maggi (2009): 383 . 
derived from radically different texts. The case of the Saddharmapundarika and the Vajracchedika is particularly telling in this regard. In spite of the popularity evinced by the Sanskrit manuscripts, neither seems to have been translated as a whole into Khotanese. The last verse of the Vajracchedikā, quoted and translated in 6.3, is also the basis of an elaborate paraphrase-commentary. ${ }^{16}$ As for the Saddharmapundarika, in spite of the rich attestations of the Sanskrit text in Khotan, all we have in Khotanese is a late metrical summary. ${ }^{17}$ Our exploration of the sources of Zambasta 6 might bring back to the table von Hinüber's suggestion that the most valued Buddhist scriptures in Khotan may have been precisely those that were never translated, as the tradent himself declares in Zambasta 23.2-6 that the Khotanese seem to value the Buddhist doctrine only if conveyed in its original Indic language (himduvau), even if this means that they understand it only partially, if at all. The quotations in Zambasta 6 seem to include sūtras that were not translated into Khotanese (e.g. Saddharmapundarika), others that were read both in original and translation (e.g. Suvarnabhāsottama), and others that as far as we know circulated only in translation (e.g. Vimalakirtinirdeśa). If the distinction between translated and untranslated sūtras did play any significant role in Khotanese Buddhism, how the evidence from Zambasta 6 fits into this model is a clear research question.

A related question, which concerns the research on Zambasta in particular, is in what way the tradent used the source materials. The quotations known so far and those presented here range from verbatim citation (e.g. $6.5=\mathrm{Lal}-$ itavistara, with poetic condensation of original five pādas into four) to what we suggest to be a poetic arrangement of a prose passage (e.g. $6.12=$ Tath $\bar{a}-$ gataguhya $[k a])$. As we have seen, the tradent did sometimes quote his sources explicitly, but as the work of some scholars has demonstrated, ${ }^{18}$ the tradent more often than not did not state explicitly that he is quoting, and the Zambasta versions with identified parallels likewise range from close translations to loose paraphrases or literary arrangements: in general, the compendial character of Khotanese Buddhist literature should be taken into account, and the specific nature of the work of the tradent needs to be understood in detail.

One must take into account also that it is unclear whether there were translations of Buddhist texts by the time of the tradent of Zambasta: are the quotations in Zambasta 6 meant to be a samplebook of yet unavailable texts? The

16 For an edition and translation see Emmerick (1977): 83-92.

17 The text was first edited in Bailey (1969): 58-61 and commented on in Bailey (1971); see, however, most recently Katayama (2014): 83-102.

18 See Régamey (1938) on Zambasta 2, Duan (2007) on Zambasta 3, Dhammadinnā or Martini on Zambasta 9 (2008), Zambasta 8 (2011), and Zambasta 4 (2014) etc. 
fact that the quotation from the Suvarnabhāsottama in 6.24 does not match the corresponding passage in the integral Khotanese translation of the text edited by Skjærvø (2004) seems to argue for this hypothesis, but any conclusion at this point is premature.

Yet another question regarding the significance of these quotations, and one that might not be obvious to most Khotanese scholars, is the extent of the influence of Chinese Buddhism in Khotan. Without exception, the sūtras that we have proposed as sources for Zambasta 6 have Chinese translations, often multiple ones. One of the present authors argues elsewhere that the Old Khotanese Bhaișajyaguruvaiduryaprabhasūtra was translated from Chinese, ${ }^{19}$ and Stephanie Balkwill has argued that the Strivivartaryākarana ${ }^{20}$ which we propose as the source of 6.42, is a pastiche of Indic sources of Central Asian or Chinese origins.

Without further preliminaries, we present in Table 1 a chart of the identified sources, followed by some methodological considerations, after which we present detailed commentary on the first five identified passages. Commentary on the remaining passages will appear in subsequent installments of this serial article.

\section{Some Practical Guidelines}

In such a textual study which lays claim to historicity, the reader would justifiably expect that every textual testimony adduced by the authors is quoted in its primary form, that is to say, the form in which it was first produced. Within the scope of the present article, we have to confess that we can hardly live up to this expectation. It is especially the case with the textus recepti in Tibetan and Chinese which have undergone a very long process of textual transmission and canonization. This is, of course, not to say that the situation of Sanskrit texts is much better. As is well known, the dating of Sanskrit manuscripts according to paleographical features is notoriously flimsy, given the dearth of those with unambiguously dated colophons. Therefore, the term 'historical' in the present context must be understood cum grano salis. In most cases, what we strive to achieve is making do with a hypothetical approximation which should be understood as an educated guess to be verified against additional evidence.

\footnotetext{
19 See Loukota (2018).

20 See Balkwill (2016): 127-148.
} 
TABLE 1 Textual sources of Zambasta 6

\begin{tabular}{|c|c|c|c|}
\hline Verse & Source & Verse & Source \\
\hline 6.1 & incipit & 6.31 & \\
\hline 6.2 & & 6.32 & \\
\hline 6.3 & Saddharmapuṇdarīka ${ }^{[\mathrm{EL}]}$ & 6.33 & \\
\hline 6.4 & Gaṇḍvyūha & 6.34 & \\
\hline 6.5 & Lalitavistara & 6.35 & \\
\hline 6.6 & & 6.36 & Ratnakaraṇda $(k a)$ \\
\hline 6.7 & Vimalakīrtinirdeśa & 6.37 & Sarvadharmāpravrttinirdeśa \\
\hline 6.8 & & 6.38 & Vajramaṇdadhāraṇī \\
\hline 6.9 & $\dagger$ & 6.39 & Ajātaśatrukaukrtyavinodana \\
\hline 6.10 & $\dagger^{21}$ & 6.40 & \\
\hline 6.11 & Avaivartikacakra & 6.41 & Hastikaksyya ${ }^{[\mathrm{Do}]}$ \\
\hline 6.12 & Tathāgataguhya $(k a)$ & 6.42 & Strīvivartavyākaraṇa \\
\hline 6.13 & Tathāgatajñānamudrāsamādhi & 6.43 & \\
\hline 6.14 & & 6.44 & Gaganagañjapariprcchā \\
\hline 6.15 & Vajracchedikāa ${ }^{[\mathrm{EL}]}$ & 6.45 & Susthitamatidevaputrapariprcchā \\
\hline 6.16 & & 6.46 & Mañjuśrībuddhakșetraguṇavyūha \\
\hline 6.17 & & 6.47 & Aśokadattāpariprcchā \\
\hline 6.18 & Candragarbha & 6.48 & \\
\hline 6.19 & & 6.49 & \\
\hline 6.20 & Ratnaketuparivarta & $6.5^{\circ}$ & \\
\hline 6.21 & & 6.51 & \\
\hline 6.22 & & $6.5^{2}$ & \\
\hline 6.23 & & 6.53 & Akșayamatinirdeśa \\
\hline 6.24 & Suvarṇaprabhāsottama ${ }^{[\mathrm{EL}]}$ & 6.54 & \\
\hline 6.25 & & 6.55 & Bodhisattvapițaka \\
\hline 6.26 & & 6.56 & Tathāgataśrīsamaya \\
\hline 6.27 & Sarvapuṇasamuccayasamādhi & 6.57 & Acintyaprabhāsanirdeśa \\
\hline 6.28 & & 6.58 & Vinayaviniścaya-Upalipariprcchā \\
\hline 6.29 & & 6.59 & \\
\hline 6.30 & & 6.60 & \\
\hline
\end{tabular}

$[\mathrm{EL}]=$ identification by Ernst Leumann. [DQ] = identification by Duan Qing. bold = quotations dealt with in the present installment.

21 Verses 6.9 and 6.10 contain proper names (i.e. Angulimāla and Kāśyapagotra), which point 
In order to facilitate such future verification, we draw the reader's attention to some guidelines with regard to the quotation of primary sources which are followed throughout this article.

The Sanskrit text of the Mahāyāna sūtra, if extant, is quoted for comparison in the first place. This does not have, it should be emphasized, the implication that the Sanskrit text is privileged over the other versions in any sense. Historically speaking, most Sanskrit manuscripts are late, especially those from Nepal, which may postdate the Tibetan translation by centuries. The rationale for our choice is rather heuristic in nature: Since every Khotanese verse dealt with below is, in all likelihood, adapted from an Indic Vorlage, it is more transparent to base the reconstruction of its original context on the Sanskrit parallel, provided the latter does not vary from its counterparts in Tibetan and Chinese significantly. If the Sanskrit text itself is no longer extant, but the pertinent passage is quoted in a Sanskrit anthology (e.g. the Śikșāsamuccaya), we attempt to reconstruct the Sanskrit parallel on the basis of the quotation that will be, in its turn, weighed against the translations in Tibetan and Chinese. ${ }^{22}$ When no Sanskrit parallel is extant or quoted, we will rely on the Tibetan and Chinese translations. In that case, the reconstruction of the Indic Vorlage is possible, but highly hypothetical, inasmuch as it is based on cognate parallels which do not necessarily predate the Khotanese verse. These uncertainties notwithstanding, for our understanding of these enigmatic verses in Khotanese, a thorough comparison with their Sanskrit counterparts or cognate parallels in Tibetan and Chinese will prove of considerable help, if prudently used as merely a practical device.

to the Angulimālīyasūtra and the Mahāparinirvāṇamahāsūtra, where interlocutors under the same names occur. However, we are not able to locate any parallel of these verses in the extant versions of these two sūtras (although the content of 6.10 seems to be reminiscent of $\S 146$ of the Mahāparinirvānamahāsūtra; cf. Habata [2013]: 111-114).

As long as the Sanskrit text makes sense in its own right, variant readings suggested by the Tibetan translation are reported in footnotes. Only in the places where the readings of the Sanskrit text are flatly impossible, emendations or conjectures are attempted on the basis of the Tibetan (or very occasionally, Chinese) translation.

The following editorial conventions are adopted throughout this paper:

*... hypothetical reconstruction of word form or etymological root

$\mathrm{A}<\mathrm{B} \quad \mathrm{A}$ is derived from or translates $\mathrm{B}$

A $>$ B A gives rise to or is translated by $B$

$\langle\ldots\rangle$ akṣara supplemented by the editor or the author

(...) variant reading(s) incorporated into the body text by the author 
As for the Tibetan texts, if they have been critically edited by modern scholars, we quote from the critical editions with all variants duly noted. ${ }^{23}$ If, as is most frequently the case, there is no critical edition yet, we quote from the Derge Kanjur, which represents the result of a careful revision by some learned Tibetan redactors and shows more often than not the standardized grammatical and orthographic forms. ${ }^{24}$ This choice should not imply that we consider the Derge Kanjur more authentic than the others. We are simply working on the assumption that the Derge edition, despite its often contaminated nature, is easier to read and translate. Variants in the other Kanjurs are consulted only at the points where the Derge reading does not make sense. So, in other words, we adopt a quasi-Bédier approach (i.e. best-manuscript approach instead of conjectural Urtext) when no critical edition is available. This inevitably results in the varying degrees to which the Tibetan translation, in the quoted form, may resemble its archetype.

The vast majority of, if not all, the Chinese texts have never been critically edited. With no ambition to fill this lacuna, we basically rely on the Taishō edition which has been revised by Japanese scholars, with rejected variants consigned to the apparatus. It is to be kept in mind that this is by no means a critical edition and, as Stefano Zacchetti points out, the variants contained in the apparatus are sometimes erroneous. ${ }^{25}$ Therefore, one should be very cautious in making historical judgements on the basis of the Taishō edition alone, a risk which we endeavor to reduce as far as possible.

\section{Buddhas in a Hair-Pore (6.4)}

\section{Text with Scansion}

paniña drau-müjsya balysa

avamāta āysäta balysa

niṣkleśa pūryau haṃtsa

ggei’śsíndi dātī cakkru

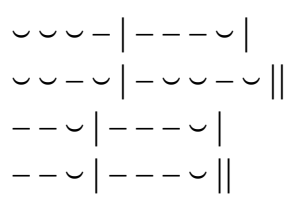

23 The various Kanjurs are referred to below by the standardized sigla, see Harrison \& Eimer (1997): xi-xiv.

24 See Eimer (1983): 93 ff., (1988): 39; and Harrison (1992a): 79 .

25 See Zacchetti (2005): 75, n. 7; 76, n. 10. For the sigla of the ancient editions of Chinese Buddhist canon, see Zacchetti ibid.: 122. 


\section{Received Translations}

\section{Leumann (1933-1936): 92}

In jedem Tropfen-Auswurf eines Priesters [in jedem dem Munde eines Priesters beim Sprechen entfliegenden viprus-Tropfen] sind ungemessene [unendlich viele] Priester (die) ausgerüstet [verbunden] mit (ihren) leidenschaftslosen Söhnen [Jüngern] zusammen das Gesetzliche Rad [das Rad des Gesetzes] rollen.

\section{Emmerick (1968): 117}

In every hair-pore of the Buddha, unlimited, adorned Buddhas, free from kleśas, O sons, together turn the Wheel of the Law.

\section{Proposed Translation}

In every hair-pore (there are) countless ornamented Buddhas; (those) Buddhas, free from afflictions, together with (their) sons, turn the Wheel of the Law.

\section{Parallel with Translation}

Proposed source: Gaṇdavyūha, cf.

Chin. (1) tr. Buddhabhadra (in 418-420AD) [T278, 9.786b21ff.]

或見一毛孔 不可說佛刹

諸佛莊嚴身 佛子眾圍遶

為轉正法輪 度脱諸群生

Some (Bodhisattvas) see in a single hair-pore

Untold (anabhilāpya) ${ }^{26}$ Buddha-fields:

All Buddhas, their bodies adorned,

And surrounded by an assembly of their Buddha-sons,

Turn the Wheel of the right Law,

So as to deliver sentient beings.

Chin. (2) tr. Śikșānanda (fl. 652-710 AD) [T279, 10.443a13ff.]

一一毛端不可說 諸佛具相三十二

菩薩眷屬共圍繞 種種說法度衆生

或有觀見一毛孔 具足莊嚴廣大刹

無量如來悉在中 清淨佛子皆充滿

26 Skt. anabhilāpya (Chin. 不可說 bù kěshuō), lit. 'ineffable', is sometimes used as a very high number, especially in the Gaṇdaryūha. See Wogihara (1968): 44b and BHSD s.v. 
In every tip of hair, (there are) untold

Buddhas, endowed with the 32 characteristic marks (mahāpuruṣalakșana),

And surrounded by the retinue of the Bodhisattvas,

Preaching the Law in various ways to deliver sentient beings.

Some Bodhisattvas contemplate a single hair-pore

Endowed and adorned with enormous Buddha-fields:

Innumerable Tathāgatas are all found therein,

(And their) virtuous Buddha-sons fill it completely.

\section{Commentary}

The image evoked in this verse bears an unmistakable affinity with a recurring cliché found in the vast and protean collection, the Buddhāvatamsaka. We encounter the very same trope (i.e. 'from a single hair-pore many Buddhas arise and turn the Wheel of the Law') in at least two scriptures found in that collection, namely the Daśabhümika ${ }^{27}$ and the Gandaryūha, in their Chinese versions. ${ }^{28}$ Of all of these, the Khotanese verse bears the closest resemblance to the Gandaryunha verses quoted above, which belong to the concluding section of the otherwise also independently circulated narrative of Sudhana's pilgrimage. ${ }^{29}$

If the verses quoted and translated above are indeed the source of the quotation, then it is likely that the words purryau and hamtsa in the Khotanese are to be construed together ('together with [their] sons') as interpreted by Leumann ("mit [ihren] ... Söhnen") rather than as a vocative followed by an adverb as read by Emmerick ("Oh sons, together"). There also might be no need to emend the form balysa at the end of the pāda to the genitive balysä as Leumann did and as apparently Emmerick did as well, to judge from his translation.

27 For the Chinese translations of this verse, see T286, 10.528a3-8 = T278, 9.571a29-b5 T287, 10.567a21-23. For the Sanskrit version of this verse, see Kondō (1936): 175f.

28 Apart from those quoted above, sporadic references to the trope are also found in other parts of the Gandaryūha, see e.g. T278, 9.683c10-11. For the Sanskrit version of this verse, see Gómez (1967): 12, K.103, which, however, does not mention the turning of the Wheel: ekaromi bahu kșetrasāgarā bodhimaṇ̣̂asthita padma-āsane | dharmadhātu vipulaṃ spharitvanā drśyate drumavareșu nāyakah || "In a single hair, where there are many oceans of fields, the Guide, having pervaded the vast Principle-foundation, is seen under every noble tree, in the Seat of Awakening on a lotus seat." (tr. Gómez [1967]:36)

29 For an up-to-date survey of textual sources of and modern scholarship on the Gandavyūha, see Osto (2008): 4-12. Unfortunately, Osto fails to take into account related materials discovered in Central Asia. 
The verses are significant because they bear witness to a stage in the development of the text earlier than that attested in the later Chinese, Tibetan and Nepalese Sanskrit textual traditions. In these latter, the lengthy pilgrimage narrative Gandaryūha, which forms the last section of the transmitted Buddhāvatamsaka, ${ }^{30}$ concludes with the well-known Bhadracaripranidhāna, whereas the Chinese translations by Buddhabhadra and Śikșānanda (T278 and T279 respectively) have a different set of verses.

These verses might have been circulated outside Khotan and China as well, for evidence of them might also be found in the magnificent Buddhist monument in Borobudur (ca. gth cent. AD). In addition to some reliefs of the second level and those of the third level which are unanimously interpreted as artistic representations of the Gandaryūha, the late Luis Gómez, to whose memory the present installment is dedicated, also suggested that the reliefs in the fourth level and in particular the outburst of niched and latticed Buddhas at the top of the monument might refer to these concluding verses (Fig. 1):

[In these verses] we are presented with visions of cosmic Buddhas and Bodhisattvas manifesting limitless Buddha-fields. In every field the Bodhisattvas perceive five Buddhas manifesting hundreds of bodies, each accompanied by a Bodhisattva. A sixth Buddha, Vairocana, evidently the most important in the group, manifests himself in different places turning the wheel of the dharma. Could this scene be the source of inspiration for the distribution of Buddhas on the circular terraces and in the niches of the Barabudur?

GómEZ (1981): 185

Gómez's question cannot be answered until more evidence comes to light. ${ }^{31}$ Be that as it may, the fact that the proposed Chinese parallel occurs after the mention of Vairocana and might indeed refer to this Buddha brings us closer to the Khotanese context. Some of the paintings studied by Joanna Williams and termed by her the 'cosmic Vairocana' seem in fact to depict the dizzying proliferation of Buddhas from the body of a Buddha (presumably Vairocana) as described in the Khotanese verse in question (Fig. 2). ${ }^{32}$

30 The Sanskrit Gandaryūha seems, as far as we can tell, to have circulated independently in Nepal and Central Asia. See Hori (2002): 113-132.

31 Fontein (2012): 171-207 disagrees with Gómez's suggestion and furnishes his own interpretation of the entire sculptural program of the fourth level as a rendering of the Bhadracari, addressing and dismissing Gómez's claims (p. 199).

See Williams (1973):117-129, figs. 8, 9 and esp. 11, where one of the Buddhas seems to display 


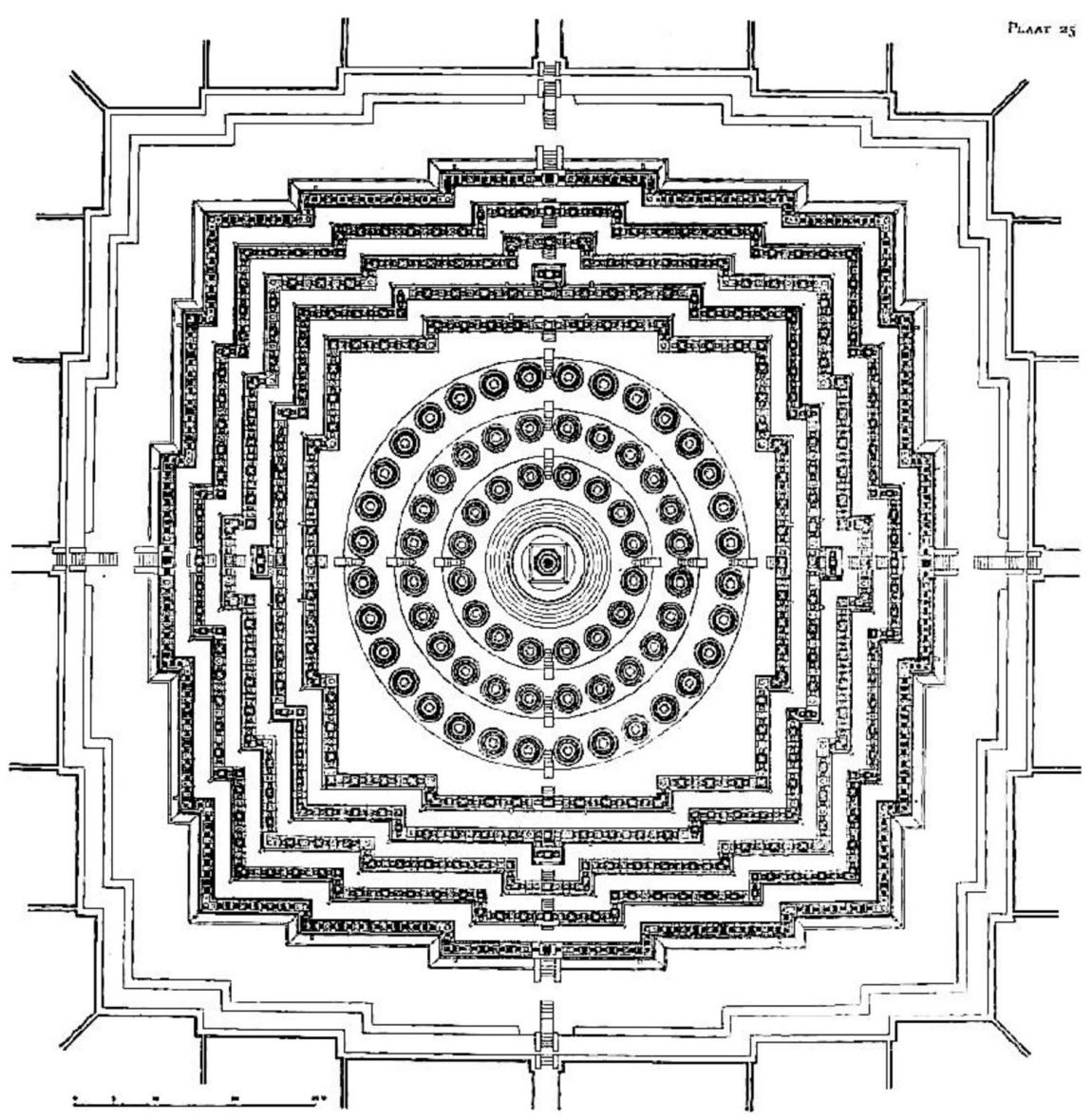

FIGURE 1 A ground plan of the Borobudur. The larger concerntric circles in the middle represent terraces; the smaller circles that dot these terraces are conic stone lattices each containing a Buddha

ADAPTED FROM KROM (1923): PL. 25

As is well known, there are important connections between the Buddhāvatamsaka and Khotan. Both of the Chinese translations of the Buddhāvatams$a k a$ have ties with Khotan: Buddhabhadra, the 5 th-century translator of T278, worked from a Sanskrit manuscript brought from Khotan; ${ }^{33}$ while the 7 thcentury Śikșānanda was himself Khotanese. Hamar Imre has put forward the

the gesture of 'turning the Wheel' (dharmacakramudrā). Williams argues that the cosmic Vairocana "constitutes the most common iconographic type in Khotanese art" (p. 120) and highlights its connection with the Buddhāvatamsaka. 


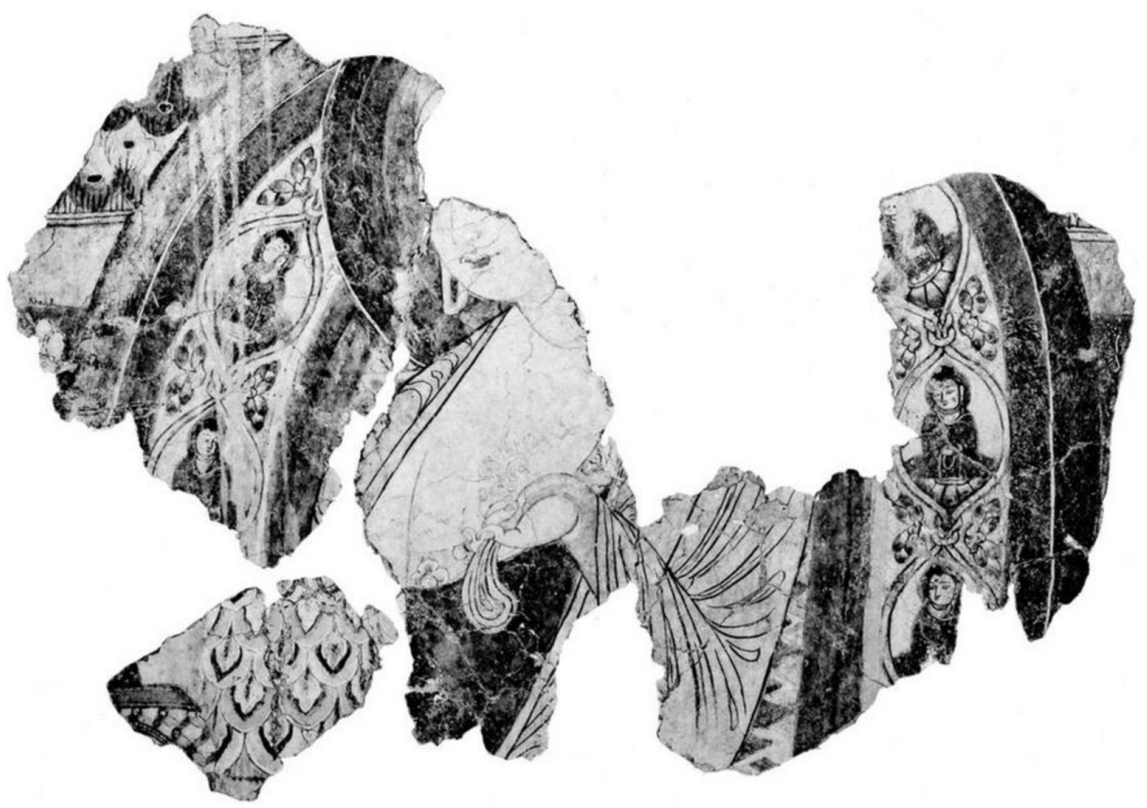

FIGURE 2 Cosmic Vairocana discovered at the site of Khädalik in Khotan

AFTER STEIN (1921): PL. XII (REPRODUCED IN WILliaMs [1973]: FIG. 9 AND COMMENTED IN PP. 118, AND 128, N. 81)

suggestion that the text was actually compiled in Khotan. ${ }^{34}$ Whether this hypothesis holds must remain open to discussion. Be that as it may, Zambasta 13, a chapter to which the earliest fragment belongs, ${ }^{35}$ makes an unequivocal allusion to Sudhana's pilgrimage $(13.47)^{36}$ and also mentions the Buddhāvatamsaka as one of the texts that the Mahāyāna has but the Śrāvakayāna lacks $(13 \cdot 13,46)$. The probable connection between the present verse and the Buddhāvatamsaka should be thus taken into account in further research into the complex textual history of the latter.

\footnotetext{
34 See Hamar (2007): 51.

35 See Maggi (2004): 184-19o.

36 Hori (2002): 113-132 has studied two fragments of the Gandaryūha from Shorchuk, one of which (i.e. SHT I 531) was copied in South Turkestan Brāhmī ( $7-8$ cent.) and thus probably brought from Khotan. Hori's tentative conclusion that the Shorchuk fragments bear more affinity with the Tibetan translation than with the later Nepalese manuscripts (p. 128) is to be examined against more identified fragments and new manuscript findings from Central Asia.
} 
The Impermanent Eye (6.5)

\section{Text with Scansion}

kauținña tceimmä aniccä

dukhi ttuśśai trāmu anātmä

kho ju ggūli o vā ggei'ha

väna àtme jō̄ätä satvä

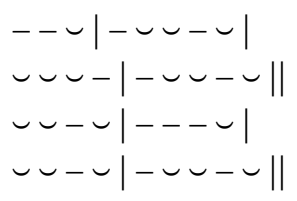

\section{Received Translations}

Leumann (1933-1936): 92

O Kauṇ̣inya, das Auge ist unbeständig, leidvoll, leer [nichtig], (und gerade)so eines Selbstes bar, wie etwa eine (dem Auge ähnliche Lehm-)Kugel oder anderseits ein (ebensolches) Holz(stück) ohne ein selbst, (ohne) Lebensgeist (und ohne) Wesen(haftigkeit) ist.

\section{Emmerick (1968): 117}

Kauṇịinya, the eye is impermanent, a woe, empty, as selfless as a ball or a stick, without self, life, being.

\section{Proposed Translation}

Kaundinya, the eye is impermanent, suffering, empty, and so devoid of self as a clump ${ }^{37}$ or a piece of wood, without self, life, being.

\section{Parallels with Translation}

Proposed source: Lalitavistara XXVI 32, cf.

Skt. [ed. Hokazono (2017): 264 ff.] = Tib. [Derge, mDo kha 201a5-6]

kauṇdinyam ālapati śākyamunị̣ svayambhūḥ̂ || $3^{1}$

älapati] ärapati $\mathrm{T1}$. śäkyamuniḥ] ${ }^{\circ}$ muniḥ $\mathrm{T1} ;$ LS omit h $(\mathrm{N} 1 \mathrm{H})$. cf. ${ }^{\circ}$ munih $\mathrm{N} 3 \mathrm{~N} 4$.

cakșur anityam adhruvam tatha śrotra ghrāṇam

$\langle$ jihvā 'pi kāya mana duhkha anātma śūnyāh

jada $\bar{a}$ tā $\rangle$ svabhāva trṇakudya ivā nirīhā

naivâtra ātma na naro ca $\langle$ na $\rangle$ jīvam asti $\| 3^{2}$

37 In his dictionary, Bailey gave the two separate entries ggūla 'clay, clay clod' and gūla 'ball' [D KS s.v.]; the second was postulated only out of etymological speculation. At least within the frame of Zambasta, it seems that only the first meaning is clearly attested (see, for example, 22.116) and, as we will argue in the following discussion, the meaning 'ball' here, as suggested by Emmerick, is unlikely. 
32a tatha] tathā T1. śrotra ghrāṇam] śrotaghrāṇam T2 (N4; RL; śrota ghrā $\left.{ }^{\circ} \mathrm{Vs}\right) ;$ srotra ghrāṇaṃ T3; śrotupāṇaṃ T4. cf. śrotra ghrānạn N2N3. $\quad 32 b\langle j i h v \bar{a}$ 'pi kāya mana $]$ om. T1T3-5; jihvā pi kāya mana T2 (N1/H; jihvāpi R; LV; jihvā 'pi s). Acc. to Tib. and from the context these words are to be restored. duḥkha] duḥkhā T2-4 (N1/HN3N4; RLVS);

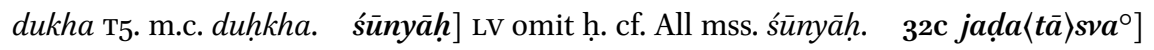
jattāḥ sva ${ }^{\circ} \operatorname{TrT}^{-} 5\left(\mathrm{~N} 3 \mathrm{~N}_{4}\right) ;$ jaḍ̄āsva ${ }^{\circ}$ T2 (N1/H; RLVs). Metrically we read jadatāsva-

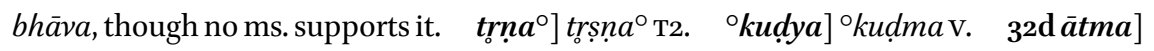
atma T2 (RL). cf. All mss. except T2 àtma. naro] vāro N1C1C2; cf. Tib. ming (=nāma); 方廣「無人無衆生」.m.c.naro.

To Kauṇḍinya speaks Śākyamuni, the self-existing one:

"The eye is impermanent, not constant; so (are) ear, nose,

Also the tongue, body, mind: (these are) suffering, selfless, empty,

Having inanimateness as their own nature, inactive like grasses or a wall.

There exists neither self, nor person, nor life."

Chin. (1) “Old Lalitavistara" tr. Dharmarakșa (in 308AD) [T186, 3.530a12 ff.]

時釋迦文佛 與拘倫談論 1

苦空非我有 ${ }^{2}$ 說其眼非常

耳鼻不能久 自然為恍惚

頭首亦自然 諸根無常聚

以如是觀者 無我無壽命

1. MSY: 語 for 論

2. MSY: 苦空非我有 transposed into the next line.

Then the Buddha Sākyamuni talked with Kauṇdinya:38

"Suffering, empty, devoid of self, (I) say, the eye is impermanent.

Ear, nose cannot last long, (and) instantly 39 become dull.

The head is also ephemeral; the sense faculties are not always in unison.

Viewed in this manner, (these are) without self, without life."

38 For the Chin. transcription of Kauṇdinya's name (拘倫 MChin. *kuว̆-lwin) cf. Gāndhārī kodịñãa, Khot. kauțimña (for the variation -ḍ-: -l-l-l-, see von Hinüber [2001]: 166f.).

39 See Boucher (1996): 243, n. 127: “[自然 zìrán] is used frequently in Dharmarakșa's texts in the sense of 'instantly' rather than in the sense of 'self-so, spontaneously, of its own." As an adjective, it is probably used in the sense of 'momentary, ephemeral'. 
Chin. (2) tr. Divākara (fl. 614-688AD) [T187, 3.607c27 ff.]

爾時世尊[...]發是妙聲, 語憍陳如等言 : 眼是無常、苦、空、無我、無人、 無眾生、無壽命, 猶如腐草雜土為牆, 危脆不實。如眼, 耳、鼻、舌、 身、意, 亦復如是。

Then the Blessed One ... issued this marvelous voice and spoke to Kaundinya and others: "The eye is impermanent, suffering, empty, without self, without person, without being, without life, just like a wall made of rotten grasses and mud, brittle and unsteady. Resembling the eye, the ear, nose, tongue, body, and mind are also once again like this."

\section{Commentary}

The mention of the Buddha addressing Kaundinya makes the derivation of the Khotanese verse from the Lalitavistara very likely. The passage-in the Sanskrit, a full stanza of vasantatilaka verse with the last pāda of the preceding stanza attached to it, i.e. five pādas from the Lalitavistara in all—occurs at a crucial point of the narrative, namely Saakyamuni's first sermon or teaching to his former companions in ascetic penance in Benares. ${ }^{40}$

The Khotanese verse occupies an interestingly awkward position in regard to the received tradition of the Lalitavistara. The narrative frame and the doctrinal point of the Khotanese verse seem to agree closely with the other versions, but the specific simile used to illustrate this doctrinal point (i.e. the impermanence of the eye) is not unproblematic. The earliest version of the Lalitavistara, which is preserved in the first Chinese translation, contains no simile at all, and while all other versions of the text do contain a simile at this point, it alludes to something like 'grasses and/or a wall' (Skt. trṇakudya, Tib. rtswa dang rtsig $p a),{ }^{41}$ rather than 'a clump or a piece of wood' (Khot. ggüli o vā ggei'ha).

It might be useful before embarking in the effort to explain these oddities to review briefly current scholarly opinions on the textual history of the Lalitavistara. The text is extant in its entirety in a Nepalese Sanskrit recension ${ }^{42}$ and a

40 It is important to note, however, that the content of this sermon or teaching is not the same in the "old" and "new" recensions of the Lalitavistara (see below). The former has a speech on interdependent causation, and the famous speech on the 'middle way' and the 'four noble truths' that appears in the latter is absent.

41 For the idiosyncratic phrase in the second Chin. translation, see our discussion below.

42 A separate Central Asian Sanskrit recension is scantily attested in fragment Or.15010/48 (ed. Karashima [2009a]: 408f.). A summary glance at Karashima's collation of the Central Asian text against Hokazono's 1994 edition of the Nepalese recension reveals that the former is separate and much more Middle Indic-looking than the latter. 
Tibetan translation which agrees closely with the latter and probably predates the early 9th century. ${ }^{43}$ The first Chinese translation (T186, the so-called "Old Lalitavistara") is attributed to Dharmarakșa and is said in later bibliographical catalogues to have been translated in $308 \mathrm{AD},{ }^{44}$ whereas a later Chinese translation (T187) dates to the 7 th century as it is attributed to Divākara who was active during this period. On the basis of internal evidence, John Brough famously suggested that Dharmarakșa's "Old Lalitavistara" was translated from a text in Gāndhārī; ${ }^{45}$ be that as it may, this is the earliest version of the text at our disposal. Recent scholarship on the textual history of the text does not agree on the relationship between this early version and later ones. The one conclusion widely agreed upon seems to be that the Nepalese Sanskrit version and the closely related Tibetan version, on the one hand, and the second Chinese translation, on the other, represent revisions of the "Old Lalitavistara" (de Jong [1998]: 251-252) that involved Sanskritization to some degree.

The above passage occurs in the "Old Lalitavistara" but the illustrative simile does not. In all other versions, the simile occupies exactly the third pāda of the stanza, ${ }^{46}$ and apparently replaces a pāda that redundantly lists the "head" and "sense faculties" as things subject to impermanence. The substitution would have been then easy to make, and it underlies all the succeeding versions.

The point of comparison in the Sanskrit text is trnakudya, which the Tibetan translators interpreted as a concatenative dvandva compound, i.e. 'grasses and/ or a wall' (rtswa dang rtsig pa). As we will show below, they were probably right in this interpretation, while Divākara's rendering — 'a wall made of rotten grass and mud' (腐草雜土為牆 fǔcǎo zátǔ wéi qiáng)—expresses, in all likelihood, an understanding of the compound as a tatpurușa ('a wall [made of] grasses'). ${ }^{47}$

'Straw and wall' as points of comparison to highlight the inertness and inactivity of the body or its parts are by no means unique or exclusive to this passage from the Lalitavistara. The statement that the body is inanimate ( jada) and the further comparison to a list of items that include 'grass' and 'wall' is, in fact, a cliché that can be found throughout early Mahāyāna literature, of which a small sample is given here:

43 It is registered in two catalogues of the earliest Tibetan translations of Buddhist texts, which were both compiled in the early 9th century (no. 75 in the lHan kar ma; no. 37 in the 'Phang thang $\mathrm{ma}$ ). See Herrmann-Pfandt (2008): 42-43 and Kawagoe (2005): 8.

44 See Karashima (2015): 123, n. 38 for the location and original text of these notices.

45 See Brough (1977): 85-95.

46 Or, rather, the portion of the text that should correspond to it in the second Chinese translation, where the whole gāthā section has been translated into prose.

47 For more information on the interpretation of this compound, see $n .53$ below. 
(1) Vimalakirtinirdeśa II §11 (after Lamotte [1987])

Skt. jado yam kāyah trṇakāṣthakudyaloștapratibhāsasadrósah / [ed. Taishō Univ. (2006): 18] = Tib. [Derge, mDo ma 183a7]

Le corps, pareil au brin d'herbe, au morceau de bois, au mur, à la motte de terre, au reflet, est inintelligent. (tr. Lamotte [1987]:133)

Cf. T474, 14.521b1of.; T475, 14.539b23f.; T476, 14.561a3.

(2) Ugrapariprcchā VIII § 25J (after Nattier [2005])48

Skt. evam eva grhapate pravrajitena bodhisattvenāranye viharatā trinagulmaușadhivanaspatikāṣthakuḍavad ātmapratibhāsavat ${ }^{49}$ saṃjñā kāye utpādayitaryā / māyāsamatā cittasyotpādayitaryā / [quot. Śikșāsamuccaya XI; ed. Bendall (1897-19o2): 199] = Tib. [Derge, dKon nga 281a45]

Just so, Householder, the renunciant bodhisattva dwelling in a wilderness must think of his body as like the grasses, shrubs, herbal plants, trees, a piece of wood or a plaster wall, that is, as an illusion [That is: He must consider it as just like an illusion]. (tr. Silk [1994]: 356, n. 1)

Cf. T322, 12.21a7 ff.; T323, 12.29a14ff.; T310, 11.478b27 ff.

(3) Ratnarāśi v §21 (after Silk [1994])

Skt. evam evāyam kāyas trṇakāṣthakuḍaapratibhāsopamo ${ }^{50}$ 'svāmiko

48 Both this quotation and that from the Ratnarāśi are translated and discussed in some detail by DiSimone 2015: 9-37. In the Ugrapariprcchā occurrence, the core of our simile is conflated or hybridized with what DiSimone focuses on in his paper, namely the compound trnagulmaușadhivanaspati 'grass, shrub, medicinal herbs, and forest trees'. Like the one under discussion here, this seems also to be, as DiSimone argues, a specifically Buddhist (p. 9), and perhaps even specifically Mahāyāna simile (p. 24), although less characterized than the Khotanese verse in terms of its specific rhetorical function.

49 The compound àtmapratibhāsavat is enigmatic and poses quite an interpretative problem, therefore, Silk regards the following māyāsamatā cittasyotpādayitaryā as an interpolated gloss on it which he translates in parentheses (p. 356, n. 1). This is not very plausible, for the so-called gloss is attested as part of the body text at least in the Tibetan version (cf. lus la rtswa dang / shing gel pa dang / sman dang / rtsig pa dang / mig yor lta bur / sgyu ma dang mtshungs pa'i 'du shes bskyed par bya ste < Skt. *trnagulmaușadhikudyapratibhāsavad māyāsamatāsamjñā kāye utpādayitaryā). The Tibetan version also points to the possibility that the enigmatic àtmapratibhāsavat could join up with the preceding compound. Should this be the case, it is possible to trace the curious reading àtma-back to *vartma- ( ${ }^{*}$-vattma-/-vātma- >-vad ätma-) in light of the occurrence in the Daśabhümika quoted below (cf. -vartmapratibhāsopamo after Rahder 1926: 18) and of an interpolation in the Tib. version of Vimalakïrtinirdeśa III $§ 5^{2}$ (cf. lus ni rtswa dang shing dang / rtsig pa dang / lam dang / mig yor lta bu'o // "Le corps est pareil à l' herbe, à l'arbre, au mur, au chemin et au reflet." tr. Lamotte [1987]: 197).

What underlies the Tibetan counterpart seems to be Skt. *trṇakudyakāṣthaloștapratibhā- 
'mamo 'parigraho niśceșțo nirvyāpāro hetupratyayayuktyā utpadyate I hetupratyayavaikalyān nirudhyate / na punar atra kaścid dharmah paramārthata utpadyate vā nirudhyate vā // [quot. Śikșāsamuccaya xI; ed. Bendall (1897-1902): 201] = Tib. [ed. Silk (1994): 475]

In just the same way one should recognize the fact that this body too is like the grasses, a wall, a tree, ... or an illusion, being masterless, without possessions, without chattels, motionless, actionless, arisen from an agglomeration of causes and conditions, and when causes and conditions are not complete unarisen; ultimately there is nothing here which is arisen or destroyed. (tr. Silk [1994]: 356)

Cf. T310, 11.645c12 ff.; T1636, 32.115b24ff.

(4) Daśabhümika I §RR (after Rahder [1926])

Skt. evam eșām sattvānām duḥkhaskandho 'bhinirvartate / ātmātmīyavigato(ätmiyavigato $\mathrm{T})$ riktas tucchaḥ $\left({ }^{\circ} \mathrm{cha} \mathrm{Ms}\right)$ śūnyo nirīho(śünyā nìrīho т) niśceșto(niśvanto MS; nistrașțaḥ T) jadas (jada т) trnakāșthakudyavartma(-vatma-T)pratibhāsopamo na caivam avabudhyanta $\left({ }^{\circ}\right.$ nte $\left.\mathrm{T}\right)$ iti / [ed. Kondō (1936): 24; and Rahder (1926): 18]

Thus the aggregate of pain of these living beings is produced. It is free from self and (what is) possessed of self, empty, vain, void, indifferent, effortless, motionless, [just like grasses, a piece of wood, a wall, a road or an illusion], (still) they cannot understand thus. (tr. Honda [1968]: 135)

Cf. T278, 9.546b22 ff.; T279, $10.182 \mathrm{c11}$ ff.; T285, 10.463 b1o ff.; T286, 10.502a24 ff.; T287, 10.540c27 ff.

(5) Sāgaramatipariprcchā II

Skt. yat kāye chidyamāne kāyasya trṇakāșthakuḍavat pratibhāsopamatāṃ ${ }^{51}$ pratyavekșate māyādharmatām ca kāyasyāvatarati / [quot. Śikșāsamuccaya Ix; ed. Bendall (1897-1902): 187] = Tib. [Derge, mDo pha 15b7] In that, when the body is being torn, [the Bodhisattva] contemplates the body's state of being similar to a reflection, like grass, wood, a wall, comprehends the illusory nature of the body. ${ }^{52}$

Cf. T397, 13.49a27; T400, 13.479c15f.

sopamo < rtswa (rtsa L) dang / rtsig pa dang / shing dang / bong ba dang / mig yor (g.yor F) lta bu ste / [ed. Silk (1994): 475].

51 The Tibetan version seems to provide us with a variant reading at this point, cf. rtswa dang rtsig pa dang shing dang rdo dang mig yor lta bur < Skt. *trṇakuḍakāșțhadrșatpratibhāsopamatām.

$5^{2}$ The translation in Bendall \& Rouse (1922): 182 ("[i]n that while the body is being torn he regards the body as like a herb or a stick or a wall, and understands that the body is illusion") seems, rather strikingly, to overlook or conflate the term pratibhāsopamatā 'the 
This list is by no means exhaustive. Throughout these passages, the most stable items in the compound that acts as a point of comparison to the body are 'grass' (trna Interestingly, digging deeper into the history of this curious simile, it turns out that its oldest core was the compound kạsțhakudya a piece of wood and/or a wall.' It is used in the Sanskrit epics ${ }^{53}$ as a metaphor for lifelessness, and once by Aśvaghoșa in Buddhacarita 12.81, where the Bodhisattva refutes the philosopher Arāḍa's ideas about ātman by adducing kāșthakuḍa as examples of ajñanna 'inability to know'.

Our contention here is that the tradents of those Mahāyāna scriptures, elaborating on an older and not specifically Buddhist compound 'wood + wall' which was often used as a clichéd metaphor of lifelessness, developed an expanded version 'grass + wood + wall + clump.' The Khotanese tradent, who may well have been familiar with the fourfold list, picked from it, at the moment of writing the verse, two items ('clump + wood') whose Khotanese designations form a beautiful alliteration (ggüli o va ggei'ha), instead of those found in the

state of being similar to a reflection'; the more recent translation in Goodman (2016): 184 ("[ $t$ ]he quality by which, when their bodies are being cut, they thoroughly understand that their bodies are like grass, sticks, and reflected images, and by which they engage with the illusory nature of the body ...") follows the Tibetan version in regarding pratibhāsa- as simply another item in the list of terms of comparison for the body; this translator also supplies a plural subject absent in the Sanskrit and the Tibetan. On account of these variances, we prefer to introduce our own translation here. The term pratibhāsopamatā is problematic: among the Chinese versions, one $(\mathrm{T} 397,13.49 \mathrm{a} 27)$ is barely more than a loose paraphrase; the other (T400, 13.479c15f.), while more literal, does not seem to contain a clear equivalent of pratibhāsopamatā. There is great variance on the terms of comparison in these different versions, but the two initial items, the ones that interest us here, namely 'grass and wood,' are present throughout.

Cf. Mahābhārata (Śāntiparvan) XII 290.82, XIII 20.52; Harivamía 20.2, 42.15; Rāmāyaṇa (Uttarakānda) VII 35.72 etc. These epic occurrences seem to support the interpretation of the compound as a dvandva, on which see for comparison also Mahābhärata (Śāntiparvan) XII 46.5 sthānukuḍaaśilābhūto nirīhaś cāsi mādhava 'turned into a column, a wall or a stone are you motionless, Krishna.' The translation by Goldman \& Goldman (2017) takes the compound as it occurs in Rāmāyana (Uttarakāṇda) I 35.62 also as a dvandva ("logs and walls", p. 322), and so do all the modern translators surveyed in p. 796, n. 62 by the Goldmans, who nonetheless notice that a tatpurușa reading ("a wall [made of] logs, a palisade") is conceivable; this is in fact how some traditional Indian commentators may have interpreted the compound, for which see in particular the gloss kāṣthavad for kāșthakudya in Nīlakanțha ad Mahäbhärata XII 290.82. The authors are indebted to one of the anonymous reviewers for the references contained in this note. 
Lalitavistara ('grass + wall'). And perhaps he sensed correctly that the latter were themselves an extrapolation from the fourfold list.

Since the pāda that contains the simile represents, as mentioned above, a modification of the old and presumably Middle Indic text, its citation in Zambasta (no later than the late $5^{\text {th }}$ century) might make it the very earliest hint at the existence of a revised and Sanskritized Lalitavistara that underlies all versions with the exception of Dharmarakșa's "Old Lalitavistara".

\section{Seeing through Not-Seeing (6.7)}

\section{Text with Scansion}

adyematīje dyemäte jsa

balysu ttatvatu daimä

padāmjjyo tcalco aysātä

hälysdä vaștāmata niśtä

$$
\begin{aligned}
& --\smile \mid-\smile-\smile-\smile \\
& -\left.\smile|-\smile \smile-\smile|\right|^{54} \\
& \smile--|-\smile \smile-\smile| \\
& -\smile-|-\smile \smile-\smile| \mid
\end{aligned}
$$

\section{Received Translations}

\section{Leumann (1933-1936): 92}

Mit einer unsehentlichen [uneigentlichen] Sehung den Priester in Wahrheit sehe ich; (denn) von dem in der frühern Strömung (der Dinge) [im frühern Weltlauf] (noch) ungeborenen Erreichten [oder: Gegenwärtigen] eine Herankunft ist (beim Priester) nicht (wahrzunehmen) [denn das Herankommen einer Gegenwart, die vordem noch nicht dagewesen wäre, gibt es beim Priester nicht].

Emmerick (1968): 117

With unseeing sight do I really see the Buddha. There is no present arrival for one unborn at the previous end.

\section{Proposed Translation}

Through the not-seeing sight do I truly see the Buddha. For (him who is) unborn at the prior end (i.e. the past life), there is no abiding in the present.

\section{Parallel with Translation}

Proposed source: Vimalakìrtinirdeśa XI §1, cf.

54 The meter of this hemistich is A: $5+12+7$. The middle colon of the meter does not require any fixed pattern in terms of syllabic quantity, but such a 12-mora segment consisting of 4 trochees is also attested in 5.98ab (see Hitch [2014]: 29) and 6.13cd. 
Skt. [ed. Taishō Univ. (2006): 109] = Tib. [Derge, mDo ma 231a3ff.]; cf. T474, 14.534b17ff.; T475, 14.554c27 ff.; T476, 14.584a15 ff.

atha khalu bhagavān vimalakirtim licchavim etad avocat / yadā tvaṃ kulaputra tathāgatasya darśanakāmo bhavasi tadā katham tvam tathāgatam paśyasi / evam ukte vimalakirti licchavir bhagavantam etad avocat / yadāham bhagavan tathāgatasya darśanakāmo bhavāmi tadā tathāgatam apaśyanayā paśyāmi pūrvāntato 'jātam aparāntato 'saṃkrāntam pratyutpanne 'dhvany asamsthitam paśyāmi

Then the Blessed One said to the Licchavi Vimalakirti: "Son of good family, when you become desirous of seeing the Tathāgata, how do you see him?" This having been said, the Licchavi Vimalakirti said to the Blessed one: "When I become desirous of seeing the Tathāgata, I see the Tathāgata through the not-seeing - I see (him as) not born from the prior end (i.e. the past life), not transmigrating from the latter end (i.e. death), not abiding in the present time."

\section{Commentary}

In the light of the identified Sanskrit source text, it is necessary to reinterpret the second hemistich which Leumann and Emmerick did not quite appropriately translate. The most conspicuous flaw is their rendering of vaștamatata as 'arrival' (Herankommen). The verb vașt- (< OIr. *ava-hišta-) means 'to stay, remain' in most cases, and is only occasionally translated 'to approach' (sGS: 120f.). The first meaning is undoubtedly to be preferred here, because its Sanskrit counterpart samsthita 'standing, abiding' is translated by the same verb in another occurrence from the Suvarnabhāsottama. ${ }^{55}$

The passage occurs at the beginning of chapter 11 of the Vimalakirtinirdeśa that tells of Vimalakirti's display of the Buddha realm called Abhirati, whence he allegedly came. The first section of this chapter deals with the transcendental nature of the Tathāgata who, according to Lamotte, "can justly said to be no different from total inexistence" due to his "absolute purity" (atyantaviśuddhitā $).{ }^{56}$ Here the discourse begins with a question raised by the Buddha as to how to see the Tathāgata. As usual, Vimalakīrti gives a characteristic Mahāyāna answer. As for the sight through which he truly sees the Tathāgata,

55 Cf. Suvarnabhāsottama 12.47 adharmapakșasamsthitah 'standing on the lawless side' > Khot. adātyānu pakșä vașțätä "he will side with lawless (people)" (Skjærvø [2004]: vol. 1, 247). It is of interest to note that both words are actually derived from the same IE root

*steh ${ }_{2}$ ' to stand'.

56 Lamotte (1987): 355 , n. 1 . 
he mentions 'the not-seeing' (apaśyanā), a term which also occurs in the following passage from the Saddharmapuṇdarīka:

so 'vabudhya traidhātukaṃ daśasu dikṣu śūnyaṃ nirmitopamaṃ māyopamam svapnamarīipratiśrutkopamạ̣ lokam paśyati / sa sarvadharmān anutpannān aniruddhān abaddhān amuktān atamondhakārān aprakāśān paśyati / ya evaṃ gambhīrān dharmān paśyati, sa paśyati apaśyanayā sarvatraidhātukam paripūrṇam anyonyasattvāśayādhimuktam //

ed. KERN/NANJIO (1912): 137

As he has arrived at true insight, he looks upon this triple world in every direction as void, resembling the produce of magic, similar to a dream, a mirage, an echo. He sees that all laws (and phenomena) are unborn and undestroyed, not bound and not loose, not dark and not bright. He who views the profound laws in such a sight, sees, as if he were not seeing, the whole triple world full of beings of contrary and omnifarious fancies and dispositions. ${ }^{57}$

tr. KERN (1884): $135 \mathrm{f}$.

Both Kern's translation here and Lamotte's interpretation (i.e. "as if there were nothing to see") are not quite satisfactory. The underlying idea is probably that "sight is false, illusory" and thus "one must not-see to truly see", as Edgerton rightly pointed out. ${ }^{58}$ The Tathāgata that he not-sees is thus characterized by three negated attributes which are related to the past, the future, and the present, respectively. In other words, Vimalakīrti truly sees the Tathāgata by seeing in him no previous birth, no future transmigration, and no present existence. In this respect, the Tathāgata is virtually no different from all phenomena and all sentient beings, which are not perceivable by sense faculties due to their 'absolute purity' or voidness. This trend of thought, having its root in some canonical sources of Mainstream Buddhism, finds great resonance in the Prajñāpāramitā literature as well as in Madhyamaka philosophy. ${ }^{59}$

57 Burnouf's understanding of the last part is slightly different: "celui-là voit ... les pensée et les dispositions diverses de tous les êtres qui remplissent la réunion des trois mondes." (tr. Burnouf [1852]: 86). This is in harmony with the Tibetan translation: khams gsum thams cad gang ba'i sems can gyi bsam pa dang mos pa tha dad pa [ed. Suzuki (2010): 9o], which seems to presuppose Skt. *sarvatraidhātukaparipūraṇam anyonyasattvāśayādhimuktam.

$5^{8}$ BHSD s.v. a-paśyanā. On the theme of 'seeing' and 'not seeing', see also Harrison \& Hartmann (2000): 186.

59 Lamotte (1987): 355, n. 1. 
The present verse is not so much a literal translation as a poetic adaptation of the Indic original in prose. A comparison makes it evident that the number of the negated attributes of the Tathāgata is reduced to two in Khotanese, with the omission of 'not transmigrating from the latter end'. Meanwhile, a slight modification is made in the juxtaposition of the two remaining attributes so as to create a metrically correct hemistich. The privative of the second participle is replaced by the negation of the corresponding abstract noun, with the first participle changed from the predicate to the subject in genitive ('not born ... not abiding ...' > 'for [him who is] unborn ... there is no abiding ...').

The existence of an Old Khotanese translation of the Vimalakirtinirdeśa is known from one single manuscript, of which we have nine complete and fragmentary folios. Judging from its language and orthography, the manuscript is written in regular Old Khotanese and almost contemporary with the earliest fragment of Zambasta. ${ }^{60}$ The persistent influence of this sūtra on Khotanese Buddhism is testified to by three quotations in the so-called Book of Vimalakirti, a metrical Buddhist catechism in Late Khotanese, two fragmentary copies of which were discovered in Dunhuang and date to the 1oth century. ${ }^{61}$ This quotation in Zambasta is so far the earliest evidence for the long-standing transmission and reception of the Vimalakirtinirdeśa in Central Asia, where it must have enjoyed no less fervent a popularity among the Khotanese Buddhists than in East Asia.

What's in a Buddha's Name? $(6.11)^{62}$

Text with Scansion

bišśo rraștatetu paysānde padāmjsyo harbišśu hälysdo bišśo ustamājsyo rraștu ttänai șei' nāma se balysä

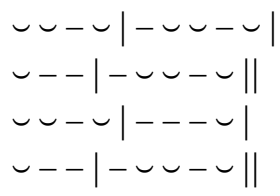

6o See Skjærvø (1986): $229 \mathrm{ff}$.

61 See Maggi (2007): 205-223.

62 For a similarly titled paper which explores the elucidations of the Buddha's epithets in the Sarvāstivādin tradition, see Skilling \& Harrison (2005): 131-156. 


\section{Received Translations}

\section{Leumann (1933-1936): $92 \mathrm{f}$.}

Die ganze frühere Richtigkeit hat er erkannt, die gesamte gegenwärtige, die ganze zukünftige in richtiger Weise; daher ist ihm jener (Ehren-)Name 'nun, der Priester'.

Emmerick (1968): 117

He has recognized all rightness, the former, all the present (and) all the future. Rightly therefore is his name 'Buddha'.

\section{Proposed Translation}

He has recognized all the past reality $(<$ tathat $\bar{a})$, all the present, and all the future correctly. Therefore, this is his name: 'Buddha' (<tathāgata).

\section{Parallels with Translation}

Proposed source: Avaivartikacakra XIII ('Tathāgata'), ${ }^{63}$ cf.

Tib. tr. Ye shes sde et al. (early 9th cent.) ${ }^{64}$ [Derge mDo, zha 285b2] | 'das dang da ltar byung ba dang | / ma'ongs de bzhin nyid lta bur | / chos kun de ltar mthong de'i phyir / / de ni de bzhin gshegs zhes brjod |

In accord with the past, the present, And the future Thusness (tathat $\bar{a})$, He saw all things thus, therefore He is called 'Thus-gone' (tathā-gata).

Chin. (1) tr. Dharmarakșa (in 284AD) [T266, 9.219b2-3]

如來知過去 當來亦如是 見諸法本無 故曰為如來

The Tathāgata knew the past, (And) the future also thus (tathā),

63 Dharmarakșa divided the sūtra into eighteen chapters, each with its own chapter heading, whereas the later Chinese and the Tibetan translations do not have separate chapter headings. Although it is unclear whether the chapter headings were Dharmarakșa's interpolations or part of the Indic Vorlage, we follow them here as an expedient means to analyze the structure and content of the sūtra.

64 It is registered in two catalogues of the earliest Tibetan translations of Buddhist texts, which were both compiled in the early 9th century (no. 105 in the lHan kar ma; no. 67 in the 'Phang thang ma). See Herrmann-Pfandt (2008): 60 and Kawagoe (2005): 10. 
Seeing things as original non-being. ${ }^{65}$

Therefore, he is called 'Thus-come' (tathā-àgata).

Chin. (2) tr. anonym (ca. early 5th cent.) [T267, 9.246c29-247a1]

若能見過去 未來亦復然

如實知諸法 是名為如來

One who is capable of seeing the past, (And) the future also thus (tathā), Knowing all things as they really are.

Such a one is named 'Thus-come' (tathā-āgata).

Chin. (3) tr. Zhiyan (in 427 AD) [T268, 9.277c24-25]

能知過去如 亦知未來如

見一切法如 是故名如來

He is capable of knowing the past Thusness (tathatā), (And) also the future Thusness,

Seeing the Thusness of all things.

Therefore, he is named 'Thus-come' (tathā-āgata).

\section{Commentary}

The word-play in the parallels to the Khotanese verse elucidating the Buddha's epithet tathāgata through its (folk-)etymological connection with tathat $\bar{a}$ is not quite obvious in the Khotanese version. However, the pun is reconstructible from the Khotanese translation vocabulary of Buddhist terms. On the one hand, balysa- (< OIr. *barza- 'the exalted one') not infrequently translates Skt. tathāgata (Suvarnabhāsottama [6x]; Sañghātasūtra [10+]), along with other epithets of the Buddha. On the other, rrașta- 'right', the adjective underlying the abstract noun rraștatāti 'truth, reality', can be used as the Khotanese counterpart of Skt. tathā 'thus', especially while analyzing the epithet of the Buddha (Skt. tathāgata > Khot. rrașta-tsūka- 'goer (along the) right (course)' (Aparimitāyuhsūtra [Duan (1992): 45 §]), rrașto tsūmato tsūte '(one who) had gone along the right course' (Sainghāțasūtra § 25.1). ${ }^{66}$ Therefore, it comes as no surprise that the abstract form of the former translates that of the latter.

65 See the discussion below.

66 Canevascini (1993): 120 traces Khot. rrașțā- tsūmatā- back to Skt. bhadracaryā 'an excellent course of conduct'. This is not quite convincing. To our mind, it is more natural to 
The idea that the Buddha is called tathāgata because he has awakened to tathatā goes back to the earliest layer of Prajñāpāramitā literature:

\section{Aștasāhasrikā Prajñāpāramitā XII}

evaṃ hi subhüte tathāgatas tathatām abhisaṃbudhya lokasya tathatām jānāti avitathatām jānāti ananyatathatāṃ jānāti / evañ ca subhūte tathāgatas tathatām abhisaṃbuddhạ saṃs tathāgata ity ucyate //

ed. MITRA 1888: 272

It is thus that the Tathāgata, after he has been enlightened as to Suchness, cognizes the Suchness of the world, its Non-falseness, its unaltered Suchness. And in consequence, just because he has been enlightened about Suchness (tathatā) is he called a 'Tathāgata.' ${ }^{67}$

tr. CONZE [1973]: 272

The Avaivartikacakra, ${ }^{68}$ a self-proclaimed Mahāyāna scripture centered on the concept of the irreversibility (avaivartika) of Bodhisattvas from the attainment of Buddhahood, ${ }^{69}$ follows the same line of thought that is characteristic of the group of scriptures categorized as 'early Mahāyāna'. As James Apple points out, this kind of word-play through semantic elucidations (nirukti/nirvacana) was instrumental in making the Mahāyāna idea(l)s more acceptable and engaging to followers of Mainstream Buddhism, especially in the incipient period. ${ }^{70}$ The sūtra was influential among later Indian commentators who cited passages from it for, among other purposes, demonstrating the Buddha's skills in rhetoric. ${ }^{71}$ For instance, both Avalokitavrata (late 7 th century) and Kamalasilia (late 8th century) relied on this sūtra to provide terms such as bhagavan,

assume that the Khot. translator(s) derived rrașta- and $t s \bar{u}$ - from Skt. tath $\bar{a}$ - and gam-, the two components of which the compound tathägata is made.

67 Compare also Vajracchedikā $§ 17 \mathrm{c}$ tat kasya hetos tathāgata iti subhūte tathatāyā etad adhivacanam "Why is that? The word 'Realized' (tathāgata), Subhūti, is a synonym for reality (tathatā)." (tr. Harrison [2006]: 152)

68 The title of the sūtra is preserved in the Abhisamayālaṃkāra commentaries by ĀryaVimuktisena (6th cent.) and Haribhadra (8th cent.), despite the incongruous reconstructions transmitted in the various Kanjur editions. See Apple (2013): 1152, 1156.

69 For the concept and its historical development in early Indian Mahāyāna literature, see Apple (2004): 211-279 and Apple (2011): 119-147.

70 See Apple (2009): 161-173.

71 See Apple (2013): 1151-1157. 
tathägata and buddha with semantic elucidations which are stylistically similar to the verse treated above. ${ }^{72}$

Compared with the Tibetan and the Khotanese versions, the three Chinese translations share noteworthy commonalities, but also show significant differences. Dealing with the three times (tryadhvan) characterized by Thusness, all the three translators threw into high relief the antithesis between 'the past' and 'the future', by omitting 'the present' in their translations. In light of the Khotanese and the Tibetan versions, there is no reason to assume that the Indic Vorlage(n) of the three translations lack 'the present'. In all likelihood, we are dealing with a case of omission by the Chinese translators who took pains to convey the same meaning through a mere ten syllables. With regard to their understandings of Thusness, Zhiyan offered a literal rendering 如 rú "manner of being" (after Lamotte) which is close to Tib. de bzhin nyid, while the other two translators resorted to exegetic elucidations. Dharmarakșa translated it as 本無 běnwú "original non-being” (after Boucher), a term which is a borrowing from the Chinese literary and religious traditions. According to Daniel Boucher, the concept of "original non-being" originated in the circle of Chinese gentry literati, who were, at that time, fond of the gnostic and ontological speculations known as 'Dark Learning' (玄學 xuánxué). ${ }^{73}$ For them, "original non-being" functioned as the ontological ground of all reality and was thus adopted by Dharmarakșa and his contemporaries to translate tathat $\bar{a}$ and its synonyms. ${ }^{74}$ But the anonymous translator in early-5th-century Liangzhou (present-day Gansu, Northwest China) had a seemingly different idea, which finds expression in the phrase 如實 rúshí 'in accord with reality'. In other words, he understood tathatā in relation to bhütakoți 'limit of truth, reality'. As a matter of fact, both terms are listed in a number of Mahāyāna scriptures as synonyms for dharmatā, which is in turn identified with the emptiness (śünyatā) and equality (samatāa of all things. ${ }^{75}$ To the issue of the synonymity of tathat $\bar{a}$, dharmadhātu and bhütakoți, a specific section of the *Mahāprajñāpāramitopadeśa is devoted, where the answer is that all the three terms are synonyms serving to designate dharmatā, usually rendered by Kumārajīva (344-413AD) as

72 See Apple (2013): 1154 .

73 See Boucher (1996): 159 .

74 This term also occurs in Dharmarakșa's translation of the Saddharmapundarīka (т263), where the ignorance of 'original non-being' is referred to as the source of the trammels of 'dependent origination' (pratītyasamutpāda). See Karashima (1998): 18f. It was also used in Lokakșema's translation of the Aștasāhasrikā (T224) to render dharmatā, vitathatā, bhütakoțitā, tathatā etc. See Karashima (2010): $44 \mathrm{ff}$.

See Lamotte (1980): 2184-2186. 
'the true characteristic of things' (諸法實相 zhūfă shíxiàng) $\cdot{ }^{76}$ While a systematic treatment of this topic must be left for another occasion, it deserves here to be noted that the Khotanese verse also testifies to the scholastic trend in equating 'Thusness' with 'truth, reality' (Skt. tathat $\bar{a}=$ Khot. rraștatāt $i$ ), which seems to have been popular among Central Asian Mahāyāna Buddhists in the 4th and 5 th centuries.

\section{The Medicine-Girl (6.12)}

\section{Text with Scansion}

aruvyau'jsa șu jīvai śūste

alysāgyo āchā jändä

tta tta dharmakāyäna balysä

biśśä anābhoggäna klaiśa

$$
\begin{aligned}
& \smile \smile-\smile \mid \cup---\smile \\
& \smile-\left.\smile|---\smile|\right|^{77} \\
& \smile \smile-\smile|-\smile \smile-\smile| \\
& \smile \smile \smile-|-\smile \smile-\smile| \mid
\end{aligned}
$$

\section{Received Translations}

\section{Leumann (1933-1936): 93}

Mit Heilmitteln hat da (der Arzt) Jivvaka ausgerüstet [oder: versehen d.h. behandelt] die Prinzessin, die Krankheiten bringt er (ihr) zum Verschwinden; so-so [ebenso] mit dem Dharma-kāya [mit seinem geistlichen Leibe] der Priester ohne Rückhalt [oder: ohne Stützpunkt, d.h. in völlig suveränem Wirken] alle Triebe (bringt zum Verschwinden).

\section{Emmerick (1968): 119}

With herbs did Jivaka treat the maiden. He removes her illness. So does the Buddha by means of the Dharmakāya remove without effort all kleśas.

\section{Proposed Translation}

With herbs has Jivaka prepared and adorned a girl, (thereby he) removes the diseases (of the world). Just so does the Buddha through the body of dharmas (dharmakāya) (remove) all afflictions (kleśa) without effort.

76 Cf. T1509, 25.297c14ff., tr. Lamotte (1980): $2188 \mathrm{ff}$.

77 The meter of this hemistich is A: $5+12+7$. For the uysnora-effect (or the Iktusgesetz after Leumann) in the case of alysāgyo (scanned $\smile-\smile)$, see Hitch (2014): 15-17. For the odd metrical behaviors of the instr. pl. ending (cf. -yau jsa - -; -yo $\bar{a}-\smile-$ ), see Hitch (2014): $27-31$; (2016): 280-282. 


\section{Parallels with Translation}

Proposed source: Tathāgataguhya $(k a){ }_{\mathrm{I}}{ }^{78} \mathrm{cf}$.

Skt. quot. Śikṣāsamuccaya viII [ed. Bendall (1897-1902): 159] = Tib. [Derge, dKon ka 109a3 ff.]; cf. T310, $11.45 \mathrm{c} 15 \mathrm{ff}$., T312, 11.708c13 ff.

sa dharmakāyaprabhāvito darśanenāpi satvānām arthaṃ karoti / śravaṇenāpi sparśanenāpi satvānām arthạ̣ karoti / tadyathāpi nāma śāntamate jīvakena vaidyarājena sarvabhaișajyāni samudānīya bhaișajyatarusaṃhātim ayam dārikārūpam krtạ̣ prāsādikạ̣ darśanīyam sukrtạ̣ sunișthitạ̣ suparikarmakrtam / sāgacchati gacchati tișthati nișīdati śayyām ca kalpayati 〈niṣkalpā nirvikalpā / tatra ye āgacchanty āturā mahātmāno rājāno vā rāja $\langle$ mahā $\rangle$ mà $\langle t y \bar{a}$ vā rājapu|trā vā śresțhigrhapatyamātyakoțtarājāno vā / tān sa jīvako vaidyarājas tayā bhaiṣajyadārikayā sārdham saṃyojayati / teșām samanantarasaṃyogam āpannānām sarvavyādhayaḥ prasrabhyante 'rogāś ca bhavanti sukhino nirvikārāḥ / paśya śāntamate jīvakasya vaidyarājasya laukikavyādhicikitsājñānaṃ yady anyeșām vaidyānām saṃvidyate / evam eva śāntamate tasya dharmakāyaprabhāvitasya bodhisatvasya yāvantah satvāh strīpurușadārakadārikā rāgadoṣamohasaṃtaptāh kāyam sprśanti / teșām sạ̣sprșțamātrāṇām sarvakleśāh prasrabhyante vigatasaṃtāpaṃ ca kāyam saṃjānanti //

He, essentially characterized by the body of dharmas, ${ }^{79}$ produces benefit for sentient beings through mere vision (i.e. seeing the body of dharmas); he produces benefits for sentient beings through mere hearing or touch. Just as, Sanntamati, when the king of physicians (by the name of) Jivaka collected all

78 It is under this title that the sūtra was known to a number of Indian commentators and philosophers who quoted from it, e.g. Candrakīrti (7th cent.), Sāntideva (7th/8th cent.), Kamalaśîla (8th cent.). See Ikuma (2013): 171, 174-175. In the *Mahāprajñāpāramitopadeśa (T1509), this sūtra seems to be quoted under such a title as ${ }^{*} G$ hhyaka(vajrapāni)sūtra (cf. 密迹[金剛]經 mìji [jīngāng] jīng); see Lamotte (1970): xxxv, §11. However, in the Tibetan translation, the sūtra is entitled Tathāgatācintyaguhyanirdeśa (cf. de bzhin gshegs pa'i gsang ba bsam gyis mi khyab pa bstan pa), which corresponds to the title of T312 (如 來不思議秘密 rúlái bùsīỳ̀ mìmì), the second Chinese translation dated in the early 11th century. Therefore, this seems to be an alternate title of the sūtra which became current at a relatively late time.

79 For the polysemous technical term Skt. prabhāvita (Tib. rab tu phye ba), see Schmithausen (1969): 109-111; (2014): 507-568. Although Schmithausen restricts the scope of his examination to the early strata of Yogācāra texts, his conclusion seems to hold good for some early Mahāyāna sūtras. The compound dharmakāyaprabhāvita- is rendered by Paul Harrison in the context of the Samādhiräjasūtra as "distinguished or constituted by the body of dharmas." (tr. Harrison [1992b]: 70) 
medicine, he made the form of a girl (composed of) a collection of medicinal herbs, which is agreeable, good-looking, well-made, well-completed, and well-prepared. She was going to and fro, standing, sitting down, and sleeping, without thinking or imagination. ${ }^{80}$ Thither came sick dignitaries: kings, prime ministers, princes, ${ }^{81}$ guild-leaders, bankers, ${ }^{82}$ courtiers, and petty rulers. Jivvaka let them unite with the medicine-girl. Immediately after the union that they consummated, ${ }^{83}$ all their diseases were appeased, and they became free from illness, sound, and unimpaired. Śāntamati, see if the knowledge of the king of physicians, Jivaka, concerning curing the diseases of the world is found among other physicians. ${ }^{84}$ Just so, Sāntamati, is the Bodhisattva essentially characterized by the body of dharmas. Whatever sentient beings - women, men, boys, girls - distressed by passion, hatred, and delusion, touch his body, all their afflictions are soothed as soon as they touch it, and they feel (their) body free from distress. ${ }^{85}$

8o The phrase 'without thinking or imagination' is missing in Bendall's edition, and here restored according to the Tibetan and Chinese versions, cf. Tib. 'ong ba'am / 'gro ba'am / 'greng ngam / 'dug gam / nyal yang rtog pa med cing rnam par rtog pa med do; Chin. 若來若去, 行住坐臥, 分別事項, 亦非分別, 非離分別 [T312, 11.708c16f.].

81 The Skt. reading rājamātrā $v \bar{a}$ does not make any sense. Our emendation *räjamahāmātyā vā rājaputrā $v \bar{a}$ is based on the Tibetan version, cf. rgyal po'i blon po chen po'am / rgyal po'i bu'am.

82 This is the English term used to render the cognate Prakrit form gahapati by Oskar von Hinüber, see Nakanishi \& von Hinüber (2014): 17 for references on this word. The suggestion that Skt. grhapati and its cognate forms convey in most Buddhist literature socioeconomic nuances richer than 'head of the household' is not new; see BHSD s.v. ("capitalist") and Chakravarti (1987): 65-93 ("landowner").

83 Although both the Tibetan and Chinese translations are quite euphemistic in this matter (cf. phrad 'met'; 和合 héhé 'to unite in a harmonious manner', 歌戲 gēxì 'to sing and play, entertain oneself'), the 'union' (samyoga) is apparently sexual. For Tib. 'phrad pa 'to meet' used sensu obscoeno, see Silk (2009): 269, n. 3 .

84 That is to say, no other physicians are in possession of this knowledge. Cf. gang sman pa gzhan la med pa 'which other physicians do not have'; 餘諸醫師無是智力 'the rest of physicians do not have this intellectual power' [T312, 11.708c21f.], 其餘醫師所不能及也 '(it is) beyond other physicians' capability' [T310, 11.45c22].

85 Compare also the recent translation by Goodman (2016): 156 . While agreeing in the general sense of the passage, we find his rendering of the verb sam-yuj- as "to have sex" correct in sense but a bit over-determined and lacking in the euphemistic flavor of the original. In light of this, we present here our own translation and notes. 


\section{Commentary}

Even a cursory look through the story suffices to reveal that both Leumann and Emmerick misinterpreted the verb śüh- (śüste sg. 3. perf. trans.) 'to prepare, adorn'. ${ }^{86}$ The source of their misunderstanding is made explicit by Leumann's bracketed remark, where he derived the semantics 'to treat' from that of the German verb versehen which means both 'to equip' and 'to look after. ${ }^{87}$ The polymath's excellent Sprachgefühl in his mother tongue blended, perhaps unconsciously, in his interpretation of the Khotanese verse, which misled Emmerick when he was translating the same verse some 50 years later. In this context, the verb corresponds to a series of (compounded) participles in the Indic version, only the last one of which, namely suparikarmakrta, is somewhat telling. Skt. parikarman, according to Böhtlingk and Roth, has a variety of meanings: 1. attendance, worship, adoration; 2 . dressing, painting or perfuming the body; 3 . cleansing, purification; 4. preparation; 5 . arithmetical computation or operation [PW s.v.]. A similar semantic range can thus be postulated for the verb śūh-, which, according to Bailey, has the following things as its objects: 1 . magical formula (vidyā), confession/profession (deśanā); 2. a woman's painting; 3. mind, confusion (Khot. bitcamphāa), the householder's gift (dakșināa ); 4 . pills, elixir [DKS s.v.]. Accordingly, different meanings can be assigned to the verb: 1. to utter, recite properly (< Skt. prayojayāmi); 2. to adorn, emblazon; 3 . to cleanse, purify; 4 . to prepare. The polysemy of the Khotanese verb is reminiscent of Chin. 莊嚴 zhuāngyán 'to ornament' which has been meticulously dealt with by Stephen Teiser. ${ }^{88}$ As is the case with zhuāngyán, whose multiple

86 There is no convincing etymology of the verb. Bailey (apud SGs: 244) proposes Khot. śüh$<$ OIr. *adi-aut- (the root goes back to IE ${ }^{*} \mathrm{~h}_{2}$ eun-dh- 'to weave'), but this hypothesis is both semantically and phonologically problematic. Therefore, an alternative etymology is suggested by Skjærvø (2004): vol. 2, 126; who considers it rather an Indian loanword: Khot. śūh-<Gāndh. *śohe-<Skt. yogaya- (For $y>s ́$ [ $|z ́|$, Gāndhārī] and $-h$ - as "Hiattilger", see von Hinüber [2001]: 174, 179). The only problem with this etymology is that it presupposes the initial ś- to be voiced, which is at odds with an Old Khotanese occurrence śsūhāta (22.96) clearly pointing to a voiceless initial consonant. Maybe it is not impossible to derive it from Middle Indic śohe- which results from an intersection of Old Indic śodhaya- and śobhaya-.

87 Cf. Duden (1981): vol. 6, s.v. versehen: "1.a) dafür sorgen, daß jmd. etw. bekommt hat; versorgen ... b) dafür sorgen, daß etw. irgendwo vorhanden ist; ausstatten".

88 See Teiser (2009): 201-237. While tending to confirm the conclusion of Huang (2001), Teiser astutely hints at the historical background against which so many meanings have come into being (p. 234): "Having begun in the early-medieval period perhaps as a vernacular expression, the word [i.e. 莊嚴 zhuāngyán] was later used in a variety of Buddhist texts, including canonical sūtras, vinaya texts, commentaries, and medieval Buddhist liturgies. The expanding usage of the word in Buddhist contexts was not so much a fundamen- 
meanings are sometimes crisscrossed with one another, two meanings of śūh(2. 'to adorn' \& 4. 'to prepare') can be assumed to do so in this verse, since the syntactic object, in the present case, is not only a female image but also a herbal preparation.

The medicine-girl here is, as Bendall rightly noted, the antipode of the poison-damsel (vișakanya $\bar{a}$, a literary motif which probably originated in ancient India and was widespread in medieval Europe. ${ }^{89}$ It was an idea entrenched in ancient India to nourish an infant girl on poison and, when she grew up into a beautiful maiden, to send her to one's political foe as a dancing girl who killed either through her gaze, her breath, her perspiration, or through sexual intercouse. The idea is attested in the Kathāsaritsāgara of Somadeva as well as other Sanskrit works, and has found its way into the Secretum Secretorum (Arab. Kitāb sirr al-āsrār), a pseudo-Aristotelian treatise probably composed in Arabic, through the Latin translations of which it became a household word in many European countries. ${ }^{90}$ Summarizing his extensive survey of a wide range of sources which remains up-to-date nowadays, N.M. Penzer concluded that " $t]$ he poison-damsel herself has no existence in actual fact, but is merely the creation of the story-teller, who derived the idea from what he saw around him."91 The same can be said of the medicine-girl that was in all probability inspired by the former. While the poison-damsel is allegedly a real girl who has been gradually inoculated against poison, the medicine-girl is no real girl at all, but a concoction prepared by a skillful physician. This difference can be accounted for through the influence of such a story as that of the wooden maiden which is well-known through the version preserved in, among others, the Mūlasarvāstivāda-Vinaya. ${ }^{92}$ The idea that female beauty is illusory and transitory in nature makes good sense from a Mainstream Buddhist point of view. But the tradent(s) of the Tathägataguhya $(\mathrm{ka})$ went a step further in transforming such an illusory and transitory image into an effective skillful means of

tal change of meaning, but rather an application of the concept of ornamentation to other realms, objects, and beings."

89 See Bendall (1922): 158, n. 1.

$90 \quad$ For detailed studies of primary sources, see Hertz (1897): 89-166, Modi (1927): 324-337, (1929): 72-93, Penzer (1952): 3-71, Kohl (1959): 324-339. The story is also mentioned by von Hinüber (2007): 64 with further references. For the reception of this motif in Persian popular literature before the Safavid period, see Hanaway (1970): $55^{-65}$.

$91 \quad$ See Penzer (1952): 71.

92 See Dutt (1947): 166-168 and Wille (199o): $7^{2}$ f. (fol. 200 ${ }^{v_{1}-9}$ ). For some useful information about the various versions of this story in Sanskrit, Tibetan, Chinese, and Tocharian A, see Dschi (1943): 323f. and Pinault (2008): 251f. 
salvation comparable with the Buddha's body of dharmas (dharmakāya). Here, we find yet another case of Mahāyānistic reworking of motifs and elements already known in the traditions of Mainstream Buddhism, which is characteristic of such a scripture as the Tathägataguhya $(k a)$.

As an early Mahāyāna text, the Tathāgataguhya $(k a)$ is doctrinally intriguing insofar as it contains an archaic version of some influential ideas, such as the Buddha's three secrets (with regard to body, speech, mind, respectively). ${ }^{93}$ Among the three, the secret with regard to speech (vāgguhya), centering on the radical dogma that the Buddha does not speak a single syllable (tathāgatenāntaśa ekākșaram api nodāhrtam ), found considerable resonance in later Buddhist scholasticism. ${ }^{94}$ The Khotanese verse is based on the passage quoted in the Sikșāsamuccaya and translated above. This passage belongs to the opening chapter of the sūtra which deals with the secret with regard to body (kāyaguhya). In that context, Vajrapāni taught the secret to Śantamati that the Bodhisattva (i.e. the Buddha Sankyamuni) has the body of dharmas characterized by Thusness (tathatā) and thus can appear in any desirable form to rescue all sentient beings. A similar idea finds expression in chapter 5 of the *Devarājapravara-Prajñāpāramitā (T231, 8.701b28-702a3), a text of dubious origin which seems to be influenced by, among others, a text not substantially different from, if not identical to, the Tathägataguhya $(k a) .{ }^{95}$ This possible influence bears witness to the significant impact that the Tathägataguhya $(\mathrm{ka})$ may well have exerted on other Mahāyāna scriptures of Indian origin.

Curiously enough, the first Chinese translation dated $288 \mathrm{AD}$ (Т310[3]) is chronologically isolated among all the complete versions of the Tathägataguh$y a(k a)$. It was not until 800 years later that the sūtra became known in China through a second Chinese version ( blance to the early-9th-century Tibetan translation. ${ }^{96}$ The only Sanskrit manu-

93 For a study of the views on the Buddha through the lens of the three secrets in the context of the Tathāgataguhya(ka), see Hamano (1987): 42-46.

94 The popularity of this viewpoint, which is attributed to the Mahāsāṃghika school in some doxographical traditions, is evinced in its quotations in scholastic treatises and commentaries, e.g. Prasannapadā XVIII, xxv [ed. la Vallée Poussin (1903-1913): 366 f., 539], Mahāyānasūtrālaṃkāra XII [ed. Lévi (1907): 79], Bodhicaryāvatārapañjikā [ed. la Vallée Poussin (1901-1914): 419], Lan்kāvatāra III, VII [ed. Nanjio (1923): 142 f., 144, 240]; see Lamotte (1987): 109 f., n. 52 . For the doctrinal grounds for the Buddha's incapability to speak and the way in which the tradent of the Tathägataguhya $(\mathrm{ka})$ coped with the problem at a time when the trikāya doctrine was not yet ripened, see most recently Wang (2017): 199202, and Ikuma (2016): 1-14.

95 See Ikuma (2012): 175-179, esp. 176.

96 It is registered in two catalogues of the earliest Tibetan translations of Buddhist texts, 
script, which was registered in a catalogue as early as in 1917 but has yet to be critically edited and published, cannot be earlier than the 17 th century, judging from its paleography. ${ }^{97}$ Thus, the identification of the Khotanese quotation, along with the those in the *Mahāprajñāpāramitopadeś $a^{98}$ and in the Sütrasamuccaya, ${ }^{99}$ provides us with one of the few testimonia of the Tathāgataguhya $(\mathrm{ka})$ in the first half of the first millennium, and should not be overlooked in any discussion on the sūtra's position in the history of Mahāyāna Buddhism.

\section{Abbreviations}

BHSD Buddhist Hybrid Sanskrit Dictionary. Edited by Franklin Edgerton. New Haven, 1953.

DKS Dictionary of Khotan Saka. Edited by Harold W. Bailey. Cambridge: Cambridge University Press, 1979.

PW Sanskrit-Wörterbuch. 7 vols. Edited by Otto Böhtlingk and Rudolph Roth. St. Petersburg, $1855^{-1875}$.

sGs Saka Grammatical Studies. By Ronald E. Emmerick. London: Oxford University Press, 1968.

SHT Sanskrithandschriften aus den Turfan-Funden. Edited by Ernst Waldschmidt et al.: Teil $1 \mathrm{ff}$., Wiesbaden, $1965 \mathrm{ff}$.

T Taishō shinshū daizōkyō 大正新脩大藏經. Edited by Takakusu Junjirō 高楠順次郎 and Watanabe Kaikyoku 渡辺海旭. 100 vols. Tōkyō: Taishō issaikyō kankyōkai 大正一切経刊行会, 1924-1934.

which were both compiled in the early 9th century (no. 27 in the lHan Kar ma; no. 44 in the 'Phang thang ma). See Herrmann-Pfandt (2008): 18-19 and Kawagoe (2005): 8.

97 For an introduction to the Sanskrit manuscript and its relation to the other versions, see Ikuma (2013): 171-175. A diplomatic edition seems to be in preparation by the same author, whose preliminary result is published in Ikuma (2014): 108-191.

98 See Lamotte (1970): xxxv.

99 See Pāsādika (1989): 24, 138. The composition of this anthology attributed (probably falsely) to Nāgārjuna is likely to predate the 6th century, since two Sanskrit fragments (IOL San 964 \& 966) from Khādalik have been identified by Seishi Karashima as belonging to this work. Both of the fragments are written in South Turkestan Brāhmī (main type) dated to the 6 th $/ 7$ th centuries. See Karashima (2009b): 263-273. 


\section{References}

Apple, James B. 2004. "An Assembly of Irreversible Bodhisattvas. Twenty varieties of the Samgha: A typology of noble beings (ārya) in Indo-Tibetan scholasticism (Part 2)." Journal of Indian Philosophy 32: 211-279.

Apple, James B. 20o9. "Wordplay-Emergent Ideology Through Semantic Elucidation: A rhetorical technique in Mahāyāna Buddhist formations." Bulletin for the Institute of Oriental Philosophy 25:161-173.

Apple, James B. 2011. "On Avaivartika and Avaivartikacakra in Mahāyāna Buddhist literature with special reference to the Lotus Sūtra." Bulletin for the Institute of Oriental Philosophy 27: 119-147.

Apple, James B. 2013. "The Influence of the Avaivartikacakra Mahāyāna Sūtra in Indian Buddhism based on its citation in Indian Buddhist commentaries." Journal of Indian and Buddhist Studies 61 (3): 1151-1157.

Bailey, Harold Walter. 1969. Khotanese Texts, vol. III. Cambridge: Cambridge University Press.

Bailey, Harold Walter. 1971. Sad-dharma-puṇdarīka-sūtra: The summary in Khotan Saka. Canberra: Australian National University, Faculty of Asian Studies.

Bailey, Harold Walter. 1985. Indo-Scythian Studies: Being Khotanese Texts, vol. vII. Cambridge: Cambridge University Press.

Balkwill, Stephanie. 2016. "The Sūtra on Transforming the Female Form: Unpacking an early medieval Chinese Buddhist text." Journal of Chinese Religions 44/2:127-148.

Bendall, Cecil. 1897-1902. Çikshāsamuccaya: A compendium of Buddhistic teaching. St. Pétersbourg: Commissionnaires de l'Académie Impériale des Sciences.

Bendall, Cecil, and W.H.D. Rouse. 1922. Śikșā-samuccaya: A compendium of Buddhist doctrine translated from Sanskrit. London: John Murray.

Boucher, Daniel. 1996. Buddhist Translation Procedures in Third-Century China: A study of Dharmarskșa and his translation idiom. Philadelphia: University of Pennsylvania.

Brough, John. 1977. "The arapacana Alphabet in the Old Lalitavistara." Bulletin of the School of Oriental and African Studies 40: 85-95.

Burnouf, Eugène. 1852. Le lotus de la bonne loi, traduit du Sanscrit, accompagné d'un commentaire et de vingt et un mémoires relatifs au Buddhisme. Paris: Impr. Nationale.

Canevascini, Giotto. 1993. The Khotanese Sañghāțasūtra: A critical edition. Wiesbaden: Dr. Ludwig Reichert Verlag.

Chakravarti, Uma. 1987. The Social Dimensions of Early Buddhism. Delhi: Oxford University Press.

Chen, Huaiyu, and Liu Zhen. 2014 "Some Reflections on an Early Mahāyāna Text: Hastikakșyasūtra." Bulletin of the School of Oriental and African Studies 77/2:293-312.

Clauson, Gerard. 1972. An Etymological Dictionary of Pre-Thirteenth-Century Turkish. Oxford: Clarendon. 
Conze, Edward. 1973. The Perfection of Wisdom in Eight Thousand Lines \& Its Verse Summary. Bolinas: Four Seasons Foundation.

DiSimone, Charles. 2015. "Remarks on an Instance of Intertextuality in the Eleventh Chapter of the Sikșāsamuccaya and the Phrase trnagulmaușadhivanaspati in Buddhist Sūtra Literature." Critical Review for Buddhist Studies 17: 9-37.

Dschi, Hiän-lin. 1943. "Parallelversionen zur tocharischen Rezension des PunyavantaJātaka." Zeitschrift der Deutschen Morgenländischen Gesellschaft 97: 284-324.

Duan Qing. 1992. Das khotanische Aparimitāyuhsūtra: Ausgabe, Übersetzung, Kommentar und Glossar. Reinbek: Dr. Inge Wezler.

Duan, Qing. 2007. "The Maitri-bhāvanā-prakarana: A Chinese parallel to the third chapter of the Book of Zambasta." In Iranian Languages and Texts from Iran and Turan: Ronald E. Emmerick memorial volume, edited by Maria Macuch et al., 39-58. Wiesbaden: Harrassowitz.

Duden. 1981. Das größe Wörterbuch der deutschen Sprache (vol. 6). Mannheim: Bibliographisches Institut.

Dutt, Nalinaksha. 1947. Gilgit Manuscripts (vol. 3, part 1). Calcutta: Calcutta Oriental Press.

Eimer, Helmut. 1988. "Arbeiten zur Überlieferung des tibetischen Kanjur am Indologischen Seminar/sFB 12 in Bonn." In Indology and Indo-Tibetology: Thirty years of Indian and Indo-Tibetan studies in Bonn, edited by Helmut Eimer, 35-42. Vienna: Verlag der Österreichischen Akademie der Wissenchaften.

Eimer, Helmut, and Paul Harrison. 1997. "Kanjur and Tanjur Sigla: A proposal for standardisation." In Transmission of the Tibetan Buddhist Canon: Proceedings of the seventh seminar of the international association for Tibetan studies, Graz 1995, edited by Helmut Eimer, xi-xiv. Vienna: Verlag der Österreichischen Akademie der Wissenschaften.

Eimer, Helmut. 1983. Rab tu 'byun் ba'i gži: Die tibetische Übersetzung des Pravrajyāvastu im Vinaya der Mūlasarvāstivādins. Nach Vorarbeiten von Frank-Richard Hamm und weiteren Materialien herausgegeben. Wiesbaden: Otto Harrassowitz.

Emmerick, Ronald E. 1968. The Book of Zambasta: A Khotanese poem on Buddhism. London: Oxford University Press.

Emmerick, Ronald E. 1977. "The Concluding Verses of the Khotanese Vajracchedikā." In Prajñāpāramitā and Related Systems: Studies in honour of Edward Conze, edited by L. Lancaster, 83-92. Berkeley: Berkeley Buddhist Studies Series.

Emmerick, Ronald E. 1989. "Book of Zambasta." In Encyclopaedia Iranica (vol. 4, fasc. 4), edited by Ehsan Yershater et al., 361-363. New York: Routledge and Kegan Paul.

Fontein, Jan. 2012. Entering the Dharmadhātu: A study of the Gaṇdaryūha reliefs of Borobudur, Leiden: Brill.

Goldman, Robert P., and Sally J. Sutherland Goldman. 2017. The Rāmāyaṇa of Valmīki, Volume viI: Uttarakāṇ da. Princetion University Press. 
Gómez, Luis O. 1967. Selected Verses from the Gandaryūha: Text, critical apparatus and translation. Yale University ( $\mathrm{PhD}$ dissertation).

Gómez, Luis O. 1981. "Observations on the Role of the Gandaryūha in the Design of Barabuḍur." In Barabudur: History and significance of a Buddhist monument, edited by Luis O. Gómez et al., 173-195. Berkeley: Asian Humanities Press.

Goodman, Charles. 2016. The Training Anthology of Santideva: A Translation of the Śikșāsamuccaya. Oxford University Press.

Hamano, Tetsunori 浜野哲敬. 1987. “Nyoraihimitsukyō no buddakan” 『如来秘密経』 の仏陀観 [= The Buddhology of the Tathägataguhya(ka)]. Journal of Indian and Buddhist Studies 36 (1): 42-46.

Hamar, Imre. 2007. Reflecting Mirrors: Perspectives on the Huayan Buddhism. Wiesbaden: Harrassowitz.

Hanaway, William L. 1970. Persian Popular Romances Before the Safavid Period. Columbia University (PhD dissertation).

Harrison, Paul. 1992a. "Meritorious Activity or Waste of Time? Some remarks on the editing of texts in the Tibetan Kanjur." In Tibetan Studies: Proceedings of the 5 th Seminar of the International Association for Tibetan Studies Narita 1989, edited by Ihara Shōren and Yamaguchi Zuihō, 77-93. Narita: Naritasan Shinshoji.

Harrison, Paul. 1992b. "Is the Dharma-kāya the Real 'Phantom Body' of the Buddha?" Journal of the International Association of Buddhist Studies 15/1: 44-94.

Harrison, Paul, and Jens-Uwe Hartmann. 2000. "Ajātaśatrukaukrtyavinodanā." In Manuscripts in the Schøyen Collection: Buddhist Manuscripts, edited by Jens Braarvig et al., vol. 1, 167-218. Oslo: Hermes Publishing.

Harrison, Paul. 2006. "Vajracchedikā Prajñāpāramitā: A new English translation of the Sanskrit text based on two manuscripts from Greater Gandhāra." In Manuscripts in the Schøyen Collection: Buddhist Manuscripts, edited by Jens Braarvig et al., vol. 3, 133-159. Oslo: Hermes Publishing.

Herrmann-Pfandt, Adelheid. 2008. Die LHan karma:Ein früher Katalog der ins Tibetische übersetzten buddhistischen Texte. Vienna:Verlag der Österreichischen Akademie der Wissenschaften.

Hertz, Wilheim. 1897. “Die Sage vom Giftmädchen.” In Abhandlungen der philosophischphilologischen Klasse der Königlichen Bayerischen Akademie der Wissenschaften 2o/2, 89-166. München.

von Hinüber, Oskar. 2001. Das ältere Mittelindisch im Überblick: 2., erweiterte Auflage.

Vienna: Verlag der Österreichischen Akademie der Wissenschaften.

von Hinüber, Oskar. 2007. "Kauțalya, die Inkarnation der 'krummen Tour', und die Wahrheit im alten Indien." In Krumme Touren: Anthropologie kommunikativer Umwege, edited by Wolfgang Reinhard, 63-76. Vienna: Böhlau Verlag.

von Hinüber, Oskar. 2014. "A Saddharmapuṇdarīkasūtra Manuscript from Khotan, the

Gift of a Pious Khotanese Family." Journal of Oriental Studies 24:134-156. 
Hitch, Doug. 2014. "Meter in the Old Khotanese Book of Zambasta." Ars Metrica 11: 1-43. Hoernle, A.F. Rudolf. 1897. Three Further Collections of Ancient Manuscripts from Central Asia. Calcutta: Baptist Mission Press.

Hokazono, Kōichi 外薗幸一. 1994. Raritavisutara no kenkyūラリタヴィスタラの研究 [= Studies of the Lalitavistara], vol. I. Tōkyō: Daitō Shuppansha.

Hokazono, Kōichi 外園幸一. 2017. "Raritavisutara no kenkyū-Honbun kōtei oyobi wayaku (dai 26 shō-ii)” ラリタヴィスタラの研究—本文校訂及び和訳 (第26章-ii) [= Studies of the Lalitavistara: Critical edition and Japanese translation (Chap. 26ii)]. Kokusai bunkagakubu ronshū 国際文化学部論集 17(4): 253-297. Kagoshima.

Honda, Megumu. 1968. "Annotated Translation of the Daśabhūmika-Sūtra." In Studies in Southeast and Central Asia, edited by Denis Sinor, 115-276. New Delhi: International Academy of Indian Culture.

Hori, Shin'ichirō. 2002. “Gạ̣davyūha-Fragmente der Turfan-Sammlung." Journal of the International College of Advanced Buddhist Studies 5: 113-132.

Huang, Zheng 黄征. 2001. “Dunhuang yuanwen 'zhuangyan', 'zixun', 'zizhuang' kaobian” 敦煌願文莊嚴、資勳、資莊考辯 [= On zhuāngyán, zīxūn, zizzhuāng in the prayer texts from Dunhuang]. In Dunhuang yuyanwenzixue yanjiu 敦煌語言文字學研究 [= Linguistic studies on Dunhuang documents], 213-220. Lanzhou.

Ikuma, Hiromitsu 伊久間洋光. 2012. “Nyoraihimitsukyō to Shōtennōhannya no taiōkankei nitsuite”如来秘密経』と『勝天王般若』の対応関係について [= On the parallelism between the Tathāgataguhya $(k a)$ and the Devarājapravara-Prajñāpāramitā ]. Journal of Indian and Buddhist Studies 6o (2): 175-179.

Ikuma, Hiromitsu 伊久間洋光. 2013. "Nyoraihimitsukyō no bonbun shahon nitsuite" 『如来秘密経』の梵文写本について [= On the Sanskrit manuscript of the Tathāgataguhya $(k a)]$. Journal of Indian and Buddhist Studies 61 (2): 171-175.

Ikuma, Hiromitsu 伊久間洋光. 2014. "Nyoraihimitsukyō bonbun shahon no honkoku: Hōgoyakuno dai 25 shō Tathāgataguhya(ka) Dhāraṇi taiō kasho”『如来秘密経』 梵文写本の翻刻: 法護訳第25章Tathāgataguhya(ka) Dhāraṇī対応箇所 [= A diplomatic edition of the Sanskrit manuscript of the Tathāgataguhya $(k a)$ : The counterpart of the Tathägataguhya (ka) Dhäraṇi in the 25th chapter in Fahu's translation]. Buzan gakuhō 豊山学報 57: 108-191.

Ikuma, Hiromitsu 伊久間洋光. 2016. “Ichijifusetsu: Nyoraihimitsukyō no shinpen wo chūshin ni”一字不説: 『如来秘密経』の神变を中心に [= Not saying a single word: with focus on the Buddha's supernatural powers in the Tathāgataguhya(ka)]. Mikkyōgaku kenkyū 密教学研究 48: 1-14.

Jaffee, Martin S. 2007. "Rabbinic Authorship as a Collective Enterprise." In The Cambridge Companion to the Talmud and Rabbinic Literature, edited by Charlotte Elisheva Fonrobert and Martin S. Jaffee, 17-37. Cambridge University Press.

de Jong, Jan Willem. 1998. "Recent Japanese Studies on the Lalitavistara." Indologica Taurinensia 23-24: 247-255. 
Karashima, Seishi. 1998. A Glossary of Dharmarakșa's Translation of the Lotus Sūtra. Tōkyō: Sōka University.

Karashima, Seishi. 2009a. "The Sanskrit Fragments 15010 in the Hoernle Collection." In The British Library Sanskrit Manuscripts (vol. II.1), edited by Seishi Karashima et.al., 335-550. Tōkyō: Sōka University.

Karashima, Seishi. 20ogb. "A Sanskrit Fragment of the Sūtrasamuccaya from Central Asia." In Pāsādikadānaṁ: Festschrift für Bhikkhu Pāsādika, edited by Martin Straube et al., 263-273. Marburg: Indica et Tibetica Verlag.

Karashima, Seishi. 2010. A Glossary of Lokakșema's Translation of the Așțasāhasrikā Prajñāpāramitā. Tōkyō: Sōka University.

Katayama, Yumi. 2014. "The Khotanese Summary of the Saddharmapuṇarīkasūtra and the Saddharmapuṇarīkopadeśa." Acta Tibetica et Buddhica 7: 83-102.

Kawagoe, Eishin 川越英真. 2005. dKar chag 'Phang thang ma. Sendai: Tōhoku Society for Indo-Tibetan Studies.

Kern, Hendrik. 1884. Saddharma-Pundarika, or, the Lotus of the True Law. Oxford: Clarendon.

Kern, Hendrik, and Nanjio Bunyiu. 1912. Saddharmapuṇdarīka. St.-Pétersbourg: Imprimerie de l'Académie Impériale des Sciences.

Kohl, Josef Friedrich 1959. "Ein Beitrag zum indischen Giftmädchenmotiv." Zeitschrift der Deutschen Morgenländischen Gesellschaft 109: 324-339.

Kondō, Ryūkō. 1936. Daśabhūmisśvaro nāma Mahāyānasūtram. Tōkyō: The Society for the Study of Mahāyāna Buddhism.

Krom, N.J. 1923. Inleiding tot de Hindoe-javaansche Kunst. 's-Gravenhage: Martinus Nijhoff.

Lamotte, É. 197o. Le Traité de la grande vertu de sagesse (Mahāprajñāpāramitāśāstra), vol. III. Louvain-la-Neuve: Institut Orientaliste.

Lamotte, É. 1980. Le Traité de la grande vertu de sagesse (Mahāprajñāpāramitāśāstra), vol. v. Louvain-la-Neuve: Institut Orientaliste.

Lamotte, É. 1987. L'Enseignement de Vimalakīrti (Vimalakīrtinirdeśa). Louvain-laNeuve: Institut Orientaliste.

Leumann, Ernst. 1933-1936. Das nordarische (sakische) Lehrgedicht des Buddhismus: Text und Übersetzung. Leipzig: Deutsche morgenländische Gesellschaft, in Kommission bei F.A. Brockhaus.

Lévi, Sylvain. 1907. Mahāyānasūtrālaṃkāra: Exposé de la doctrine du Grand Véhicule. Paris: Bibliothèque de l'École des Hautes Études.

Loukota, Diego. 2018. "Was the Khotanese Bhaișajyaguruvaiduryaprabhasūtra Translated from Chinese?" forthcoming, Journal of the American Oriental Society.

Maggi, Mauro. 2004. "The Manuscript T III S 16: Its importance for the history of Khotanese literature." In Turfan Revisited: The first century of research into the arts and cultures of the Silk Road, edited by D. Durkin-Meisterernst et al., 184-19o. Berlin: Dietrich Reimer. 
Maggi, Mauro. 2007. "Vimalakīrtinirdeśasūtra Quotations in the Khotanese Book of Vimalakìrti." In Iranian Languages and Texts from Iran and Turan: Ronald E. Emmerick memorial volume, edited by Maria Macuch et al., 205-224. Wiesbaden: Harrassowitz.

Maggi, Mauro. 20o9. "Khotanese Literature." In The Literature of Pre-Islamic Iran: companion volume I to A History of Persian Literature, edited by Ronald E. Emmerick and Maria Macuch, 330-417. London: I.B. Tauris.

Maggi, Mauro. 2015. "A Folio of the Ratnakūța (Käśyapaparivarta) in Khotanese." Dharma Drum Journal of Buddhist Studies 法鼓佛學學報 17: 101-143.

Martini, Giuliana (Bhikkhuṇi Dhammadinnā). 20o8. "Tracing the Sources of the Book of Zambasta: The case of the yakșa painter simile and the Kásyapaparivarta." Journal of Inner Asian Art and Archaeology 3: 91-97.

Martini, Giuliana (Bhikkhuṇ̄ Dhammadinnā). 2011. "A Large question in a Small Place: The transmission of the Ratnakūța (Käśyapaparivarta) in Khotan." Annual Report of the International Research Institute for Advanced Buddhology at Sōka University 14: $135^{-183}$.

Martini, Giuliana (Bhikkhuṇ̄ Dhammadinnā). 2014. "Mahāratnakūṭa Scriptures in Khotan: A quotation from the Samantamukhaparivarta in the Book of Zambasta." Annual Report of the International Research Institute for Advanced Buddhology at Soka University 17: 337-348.

Mayer, Robert. 2015. "gTer ston and Tradent: Innovation and conservation in Tibetan treasure literature." Journal of the International Association for Buddhist Studies 3637: 227-242.

Mitra, Raja. 1888. Ashțasáhasriká: A collection of discourses on the metaphysics of the Maháyána school of the Buddhists. Calcutta: Baptist Mission Press.

Modi, Jivanji Jamshedj. 1927. "The vish-kanyâ or Poison-Damsels of Ancient India: Illustrated by the story of Susan Râmashgar in the Persian Burzo-Nâmeh." Folklore 38/4: 324-337.

Modi, Jivanji Jamshedj. 1929. "The Story of Alexander the Great and the Poison-Damsel of India: A trace of it in Firdousi's Shāh-Nämeh." In Asiatic Papers: Papers read before the Bombay branch of the Royal Asiatic Society (vol. 4), 75-93. Bombay: Times of India.

Nakanishi, Maiko, and Oskar von Hinüber. 2014. Kanaganahalli Inscriptions. Tōkyō: Sōka University.

Nanjio, Bunyiu. 1923. The Lañkāvatāra Sūtra. Kyōto: Ōtani University Press.

Nattier, Jan. 2005. A Few Good Men: The Bodhisattva Path according to the Inquiry of Ugra (Ugrapariprcchā). Honolulu: University of Hawai'i Press.

Osto, Douglas. 2008. Wealth and Women in Indian Mahāyāna Buddhism: The Gandavyūha-sūtra. London and New York: Routledge.

Pāsādika, Bhikkhu. 1989. Nāgārjuna's Sūtrasamuccaya: A critical edition of the mDo kun las btus pa. Copenhagen: Akademisk Forlag. 
Penzer, Norman M. 1952. Poison-Damsels and Other Essays in Folklore and Anthropology. London.

Pinault, Georges-Jean. 2008. Chrestomathie tokharienne: textes et grammaire. LeuvenParis: Peeters.

Rahder, Johannes. 1926. Daśabhūmika-Sūtra. Leuven: J.-B. Istas.

Régamey, Constantin. 1938. The Bhadramāyākāravyākaraṇa. Warsaw: Nakladem towarzystwa naukowego warszawskiego.

Schmithausen, Lambert. 1969. Der Nirvāṇa-Abschnitt in der Viniścayasaṁgrahaṇi der Yogācārabhümih. Vienna: Verlag der Österreichischen Akademie der Wissenschaften.

Schmithausen, Lambert. 2014. The Genesis of Yogācāra-Vijñānavāda: Responses and reflections. Tōkyō: The International Institute for Buddhist Studies.

Silk, Jonathan A. 1994. The Origins and Early History of the Mahāratnakūța Tradition of Mahāyāna Buddhism: with a study of the Ratnarāsisūtra and related materials. University of Michigan (PhD dissertation).

Silk. Jonathan A. 2009. Riven by Lust: Incest and schism in Indian Buddhist legend and historiography. Honolulu: University of Hawai'i Press.

Skilling, Peter, and Paul Harrison. 2005. "What's in a Name? Sarvāstivādin interpretations of the epithets 'Buddha' and 'Bhagavat.” In Bukkyō to Jyaina kyō: Nagasaki Hōjun hakushi koki kinen ronshū 仏教とジャイナ教：長崎法潤博士古稀記念論集, 131-156 [700-675]. Kyōto: Hirakuji shoten.

Skjærvø, Prods Oktor. 1986. "Khotanese Fragments of the Vimalakītinirdeśasūtra." In Kalyānamitrārāgaṇam: Essays in honour of Nils Simonsson, edited by E. Kahrs, 22926o. Oslo: Norwegian University Press.

Skjærvø, Prods Oktor. 2004. The Most Excellent Shine of Gold, King of Kings of Sutras: The Khotanese Suvarnabhāsottamasūtra. Cambridge, Mass.: Harvard University, Department of Near Eastern Languages and Civilizations.

Skjærvø, Prods Oktor. 2012. "Khotan, an Early Center of Buddhism in Chinese Turkestan." In Buddhism across Boundaries: The interplay of Indian, Chinese, and Central Asian source materials, edited by John R. McRae and Jan Nattier, 106-141. (Digital reissue of Collection of Essays 1993: Buddhism across Boundaries-Chinese Buddhism and the Western Regions. Taipei 1999.)

Stein, Marc Aurel. 1921. Serindia, Vol. 4, Plates. Oxford: Clarendon Press.

Suzuki, Takayasu. 2010. "Dam pa'i chos pad ma dkar po (v), sMan gyi le'u (Saddharmapuṇ̂rīka [v], Oșadhiparivarta): Romanized transliteration from the Phug drag manuscript Kanjur." Bulletin of the Faculty of Intercultural Studies Yamaguchi Prefectural University 16: 81-93.

Taishō Univ. 2006. Bonbun Yuimakyō: Potara kyū shozō shahon ni motozuku kōtei 梵文 維摩経: ポ夕ラ宮所蔵写本に基づく校訂 [= Vimalakirtinirdeśa: A Sanskrit edition based upon the manuscript newly found at the Potala Palace]. Tōkyō: Taishō daigaku shuppankai. 
Teiser, Stephen T. 20og. "Ornamenting the Departed: Notes on the language of Chinese Buddhist ritual texts." Asia Major 22 (1): 201-237.

de la Vallée Poussin, Louis. 1901-1914. Bodhicaryāvatārapañjikā. Calcutta: Asiatic Society of Bengal.

de La Vallée Poussin, Louis. 1903-1913. Mūlamadhyamakakārikās (Mādhyamikasūtras) de Nāgārjuna: Avec la Prasannapadā commentaire de Candrakīti. St.-Pétersbourg: Académie Impériale des sciences.

Wang, Junqi 王俊淇. 2017. “Nyoraihimitsukyō ni okeru ichijifusetsu ron”『如来秘密 経』における一字不説論 [= The theory of the Buddha not preaching a single word in the Tathāgataguhya (ka)]. Journal of Indian and Buddhist Studies 65 (2):199-202.

Wille, Klaus. 199o. Die handschriftliche Überlieferung des Vinayavastu der Mūlasarvāstivādin. Stuttgart: F. Steiner.

Williams, Joanna. 1973. “The Iconography of Khotanese Painting." East and West 23 (1/2): 109-154.

Wogihara, Unrai 荻原雲来. 1968. Kanyaku taisho Bonwa daijiten 漢訳対照梵和大辞典. Tōkyō: Suzuki Research Foundation.

Zacchetti, Stefano. 2005. In Praise of the Light: A critical synoptic edition with an annotated translation of chapters 1-3 of Dharmarakșa's Guang zan jing, being the earliest Chinese translation of the Larger Prajñāpāramitā. Tōkyō: Sōka University.

Zürcher, Erik. 2007. The Buddhist conquest of China: The spread and adaptation of Buddhism in early medieval China. Leiden: Brill. 